\title{
Metodik til studiet af strategiske ledelsesprocesser i organisationer ${ }^{1}$
}

\author{
Jorgen Gulddahl Rasmussen
}

\begin{abstract}
Denne artikel handler om at skabe viden om en hverdagspraksis, der sjældent er sat ord på. Den behandler de ledelsesprocesser, der i virksomheder producerer strategi og omsætter sådanne strategier i produktive handlinger. Det er processer, der i små og mellemstore virksomheder er præget af intuition og af meget uformelle samspil mellem virksomhedsledere og medarbejdere. Metodikken er en videreudvikling af de metoder til produktion af kvalitative data, som FIRM-gruppen ${ }^{2}$ har eksperimenteret med gennem nogle år. Artiklen kan ses som en afrapportering af et flerårigt metodeudviklingsarbejde. Da erfaringer fra sådanne virksomheder viser, at strategiske processer i høj grad udvikler sig gennem uformel kommunikation, og at lederes intuition spiller en meget stor rolle, arbejder metodikken med en struktureret udviklingsdialog mellem et mindre antal virksomhedsledere med strategiske opgaver og forskere. Denne udviklingsdialog har til formål at følge og forstå de processer, der skaber ledernes egne praksisrelaterede "teorier" for strategisk handling. Efter en præsentation af temaet gennemgås metodikkens praktiske fremgangsmåde med undersøgelser i en række virksomheder, opbygning af cases i samarbejde med ledere fra disse virksomheder, diskussion af disse og foreløbige konklusioner hen mod de næste trin i metodikken. Artiklen er skrevet samtidigt med arbejdet på et igangværende forskningsprojekt og vil derfor både være en præsentation og en udvikling af muligheder og vanskeligheder i metodikken.
\end{abstract}

Key words: Kvalitativ metode, interaktion mellem forskning og udvikling, samspil med feltet, dynamiske studier af strategiprocesser.

Please cite this article as:

Rasmussen, J.G. (2010). Metodik til studiet af strategiske ledelsesprocesser i organisationer. Qualitative Studies, 1(2): 129-158.

\footnotetext{
${ }^{1}$ Jeg ønsker at takke FIRM-forskningsgruppen kommentarer til en ufærdig udgave af denne artikel, at takke professor Erik Laursen for mange nyttige kommentarer til denne udgave i en foreløbig form, og ganske særligt ønsker jeg at takke Mette Vinther Larsen for hendes meget betydningsfulde bidrag både i udviklingen af metodikken i StraWay-projektet og i den praktiske medvirken i dette.

${ }^{2}$ Firm-gruppen (Firm, Innovation, Relationship \& Mangement) er en af forskningsgrupperne i Institut for Erhvervsstudier, Aalborg Universitet, som bl.a. arbejder med kvalitative studier af virksomhedsstrategi. Når termerne vi og vores anvendes i artiklen omfatter den forskellige kombinationer af medlemmer i FIRM.
} 
"..it is what is unsaid and unseen that is of interest"

(Chia and Holt: Strategy without Design, s. 99)

\section{Indledning}

"Vi satser $i$ virksomheden på at udvide de ydelser, vi tilbyder vore største kunder, så vort produkt ikke alene er det konkrete halvfabrikata, vi sælger. Vi tilbyder $i$ stedet sammen med vore store kunder at medvirke $i$ en integreret udvikling af vort halvfabrikata og resten af kundens produkt på en måde, så kundens samlede produkt får den størst mulige attraktivitet overfor slutbrugere. Det er allerede lykkedes os at involvere flere store kunder i denne proces." Sådan beskrev direktøren for en af de virksomheder, der deltager i vores igangværende forskningsprojekt, StraWay, ${ }^{3}$ i store træk sin strategiske ledelsesopgave, da vi i september 2009 mødtes med ham første gang. Siden da er denne beskrivelse gradvist blevet uddybet.

Det drejer sig om en proces, der for virksomheden vil resultere i en ny måde at drive forretning på. En måde der allerede har ført til et betydeligt mersalg. Der er tale om en innovativ idé, som kan få afgørende strategisk betydning. Det er samtidig en idé, der er groet frem næsten af sig selv i det daglige arbejde, og er således ikke noget, ledelsen i virksomheden har analyseret sig frem til eller kopieret fra andre. Og intuitivt for ledelsen føles ideen rigtig.

Direktøren har, primært sammen med sin souschef, på den måde tilsyneladende fundet et guldæg, som kan være med til at bringe virksomheden styrket ud af finanskrisen. Den store opgave, ledelsen nu står med, er at få egne sælgere til at forstå og kunne anvende de teknikker, der er nødvendige for at få dette nye udviklings- og salgskoncept til at fungere over for de øvrige store kunder. Det er ikke tilstrækkeligt, at direktøren er i stand til at overbevise enkelte kunder om løsningens fortræffelighed. Den skal også kunne praktiseres af virksomhedens meget erfarne sælgere. Han ser, at dette skal skabes i et samspil mellem den nye idé og eksisterende kompetencer. Der er her tale om at sælge på en anderledes måde, nemlig gennem at overbevise kundens topledelse om ideens fortræffelighed gennem at demonstrere, hvilken forøget værdiskabelse der ligger i denne. I det tidligere strategiske koncept har det været kundens indkøbere, sælgeren har skullet påvirke.

Udfordringen er, at det kan være vanskeligt for sælgerne at leve op til en kompetence, direktøren har udviklet og ønsker, at de udviser i deres arbejde, og det har medført en række konkrete besværligheder for sælgerne. Så ét er for direktøren at udvikle en innovativ idé med strategisk rækkevidde, men en anden særdeles vigtig del i strategisk ledelse er hos alle - sælgere, designere, logistikere og ledere - at udvikle de praktiske kompetencer, der er nødvendig for at realisere ideen. Den løbende daglige strategiske ledelsesudfordring er dermed at få en sådan idé til at blive til virkelighed og en del af den daglige praksis. Denne artikel handler om udvikling af en metodik til at undersøge, hvordan sådanne hverdagsprocesser foregår, og det ovenstående eksempel kan ses som et indgangsbillede på en strategisk proces.

\footnotetext{
3 StraWay er et flerårigt forskningsprojekt, som blev indledt i 2009 i samarbejde med en dansk brancheorganisation med det formål at undersøge dagligdagens strategiske ledelsesprocesser i et mindre antal virksomheder, og er en efterfølger til det StraCon-projekt, som tillige indgår i artiklen. Begge projekters indhold og metode vil hen gennem denne artikel blive beskrevet i detaljer og danne grundlag for en væsentlig del af diskussionerne af kvalitativ metode.
} 
Den væsentligste interesse for at udvikle teori for strategi i virksomheder har gennem tiden været baseret på at opbygge strukturmodeller for markeder og konkurrence (se f.eks. Ansoff \& McDonnel 1990; Lynch 2003; De Witt \& Meyer 2010). Kort fortalt tager en strukturmodel udgangspunkt i, hvad det er for betingelser, de markeder, virksomheden arbejder på, stiller til denne, og modellen anviser derudfra, hvordan ledelsen skal strukturere sine strategiske aktiviteter (Johnson, Scholes \& Whittington 2008: 301). Meget omtalte er i den sammenhæng en række modeller opbygget af den amerikanske strategiforsker Michael Porter. Mindre belyst er, hvorledes og om sådanne modeller specifikt anvendes i konkret virksomhedsledelse (se som udgangspunkt: Mintzberg, 1994). Undersøgelse af dette fænomen var, hvad FIRM-gruppen satte sig for at arbejde med i 2005. Dette er blevet undersøgt gennem tre forløb, som har i alt involveret tre gange fem topledere og deres femten virksomheder i et projekt ved navn StraCon-projektet.

Metodikken, der diskuteres i denne artikel, er udviklet på grundlag af disse forløb og i det igangværende forskningsprojekt. Både de tidligere forløb og det nuværende projekt arbejder med at skaffe viden om en række uformelle hverdagshandlinger og brug af intuition hos ledere som redskaber til at udvikle og udfolde virksomhedens strategi. Dette analyseres - lidt utraditionelt gennem interaktion mellem forskere og ledere fra forskellige virksomheder og gennem deres fælles fortolkninger af konkrete strategiske iagttagelser. Artiklen diskuterer i relation hertil en række muligheder og kritiske punkter i metodikken.

Det fænomen, der undersøges, kan genfindes også i gængse lærebøger om strategi (Johnson et al. 2008: 423) og handler om lederes håndtering af samspil mellem en organisations omgivelser, ressourcer og mål, hvilket kan stå som definition på strategisk ledelse i praksis. Men formålet med undersøgelsen må siges at ligge uden for det, som i lærebøgerne er hovedstrømmen i strategisk teori. Interessen i vore analyser er hverdagsprocesser, mere end de officielle strategidokumenter. Det er en interesse, som dog kan findes i anden strategilitteratur (Ahlstrand, Lampel \& Mintzberg 1998; Cummings 2002; Jarzabkowski, Balogun \& D. Seidl 2007; Carter, Clegg \& Kornberger 2008; Chia \& Holt 2009).

\section{Metodikkens paradigmatiske udgangspunkt}

Den fremgangsmåde, som forskningsarbejdet følger, har sin inspiration i et fortolkende paradigme inden for virksomhedsteori (Arbnor \& Bjerke 1977; Arbnor \& Bjerke 2009). Metodikken er samtidig i høj grad baseret på produktion af kvalitative data (Andersen 2008) og bygger i høj grad på dialog mellem aktør og forsker (Kvale 2000).

Et fortolkende paradigme knytter sig til en bestemt ontologi. En tilgang, som har en fænomenologisk inspiration og derfor ikke baserer sig på, at erkendelse er endelig, men at resultater af forskningsprojekter kun er "valid until further notice" (Schutz 1970:49). Steiner Kvale skriver om det meningsløse i at lede efter "den egentlige mening" (Kvale 2000: 220), hvilket tillige er en opfattelse, der deles i det her anvendte paradigme. Og ud fra dette paradigme skal resultaterne af studiet af sådanne erkendelsesprocesser i højere grad måles ud fra "is it interesting? is it relevant? is it beautiful?" end ud fra "is it valid? is it reliable? is it Science?" (Czarniawska 2004:136). I sådanne processer møder fortolkninger løbende andre fortolkninger, og de synteser, der opstår heraf gennem relationerne mellem aktører og gennem tolkning af fænomener, ændrer ikke 
kun strategier, men forandrer virksomheden i små skridt (Chia \& Tsoukas 2002; Gergen \& Thatchenkery 2004; Weick, Sutcliffe \& D. Obstfeld 2005).

Undersøgelsen og dens metodik bygger videre på metoder i en række forskningsprojekter, flere af os har været involveret i gennem de seneste ti år (Rasmussen 2001; Jørgensen og Rasmussen (red.) 2005; Laursen og Rasmussen (red.) 2007; Larsen og Rasmussen 2007; Gregersen, Lind og Rasmussen 2009; Gelsing, Gjerding, Nielsen, Rasmussen \& Vinding 2008; Rasmussen 2006; Larsen \& Rasmussen 2008). Endvidere er metodikken udviklet i samspil med metodeudvikling i en igangværende empirisk undersøgelse af strategiske processer i én stor servicevirksomhed (Larsen, 2008).

Metodikkens vægt på et fortolkende paradigme fokuserer på følgende elementer: praksis: det ledere gør (Carter et al. 2008), hverdag: det, som dagligt tages op til behandling (Jarzabkowski et al. 2007), livsverden: lederens samlede forståelse af sin hverdag (Schutz \& Luckmann 1973), aktiv dialog: problemløsende dialog mellem aktører, her ledere (Arbor \& Bjerke 2009), forskerens involvering i forskningsprocessen: samspillet mellem ledere og forskere (Clark \& Fast 2008) og ledernes rolle i strategiprocesser: alle praktiske dimensioner af ledelse (Johnson et al 2008).

Praksis, hverdag og livsverden sætter sigtepunkter for metodikken, som derigennem søger at fange det gængse, de daglige handlinger og det, at en organisation er i stadig bevægelse og forandring gennem inkrementelle skridt (Chia \& Holt 2008). Ledernes rolle både i virksomhedernes strategiprocesser og som direkte involverede sammen med forskerne i produktion af ny erkendelse om dagligdagen peger på de typer af interagerende relationer, der er et væsentlig led i metodikken. At arbejde ud fra dette paradigme består i at lægge dokumenterede billeder af disse processer frem. Billeder, som både de deltagende ledere og læsere med interesse for feltet kan tage op til overvejelse. Men det vil være i strid med de forudsætninger, paradigmet sætter op, at tro, det er muligt at arbejde hen mod en generel "Grand Theory" for feltet.

\section{Strategisk ledelse som forskningsfelt}

Set med traditionelle briller og ud fra hovedstrømmen i den hidtidige udvikling i strategiteori kan den forskningsintention, der ligger bag opbygningen af denne metodik, for nogen virke irrelevant. Denne intention handler anskuet ud fra hovedstrømmen i strategiteori tilsyneladende om studiet af ganske almindelige hverdagsaktiviteter i virksomheder. Aktiviteter, som kun i begrænset grad kan have strategisk interesse. Det vil være et synspunkt, der vil kunne blive fremført. Men det er erfaringer fra blandt andet tidligere undersøgelser, vi har arbejdet med, og fra en voksende gruppe af forskningsprojekter om strategi, som ofte går under betegnelsen "Strategy-as-Practice" (Whittington, Molloy, Mayer \& Smith 2006; Whittington, Jarzabkowski, Mayer, Mounoud, Nahapiet \& Roleau 2003; Johnson, Langly, Melin \& Whittington 2008 B), at disse mere hverdagsagtige og på erfaring og intuition baserede handlinger spiller en betydelig rolle for at få en strategi til at lykkes. Det er tillige noget, som mange praktiserende ledere giver udtryk for, når det drejer sig om ledelseshandlinger, som berører relationer mellem omgivelser, ressourcer og mål i virksomheder (Larsen \& Rasmussen 2008B). Handlinger baseret på intuition er sådanne, som lederne forklarer ved, at det gjorde de bare, fordi det var det naturlige at gøre i situationen. Sådanne handlinger er ikke baseret på en forudgående logisk opbygget kalkulering, men bruger implicit nogle af de erfaringer, der er internaliseret gennem arbejdet som leder. 
Med det udgangspunkt var der for os skabt interesse og mulighed for at arbejde med dette forskningsfelt. Det kræver efter vores opfattelse ikke kun en aktiv indsats fra forskere. Det kræver tillige, at praktiserende ledere medvirker aktivt. Ikke kun for at ledere selv reflekterer over egne handlinger, men for at bidrage til en fælles erkendelse, som rækker ud over den enkelte strategiske proces og den enkelte virksomhed. Der skulle udvikles en metodik, der både er praktiserbar og gennemskuelig for forskere som for ledere. Dette skulle ske med udgangspunkt $i$, at strategiske processer i virksomheder altid vil bære præg af, at de udgør en bevægelse fra noget kendt til noget nyt og kun delvist kendt. Dette sker ofte gennem, at ledere tilsyneladende handler helt intuitivt, og at sådanne ledelsesprocesser er vedvarende uden fast start- og slutpunkt. Praktisering af strategisk ledelse sker dag efter dag.

\section{Struktur eller proces?}

StraCon-forløbene peger på, at den viden, som ledere har om strategiske muligheder og problemer, altid er foreløbig og kontinuert vil blive erstattet af ny midlertidig erkendelse. Dette kan siges at stå i modsætning til mange af de strukturmodeller, som ofte præger de teoretiske forestillinger om strategi, og hvor en virksomhed har én og måske kun én bedste model for sin strategiske adfærd. Det er samtidig således, at den offentlige diskurs om strategi både i teori og praksis i høj grad bygger på sådanne strukturelle løsninger - gerne med en forestilling om, at der kan nås én optimal løsning, og ofte ud fra eksempler, der er blevet kanoniseret som succeser. Dette er med til at gøre det at diskutere strategi som hverdagsprocesser til noget mere usædvanligt og måske til noget, der ikke hos alle vækker det store bifald.

Strukturelle syn på ledelse bygger også ofte på, at erkendelse, som ikke direkte kan præsenteres i tal og i officielt godkendte beretninger, kan forekomme virksomhedsledere og for den sags skyld forskere lidt suspekt. Ledere er vant til at præsentere og argumentere ud fra nedfældede regnskaber, beretninger og planer. Derfor betyder studiet af strategisk praksis et ændret fokus i retning af en fælles diskussion om, hvad man intuitivt gør i hverdagen og med hvilke intentioner. Det er en form for perspektivskifte, som for mange ledere er uvant og ikke helt enkel. Når handlinger baseret på intuition og praktiske erfaringer skal diskuteres, er det officielle og formelle sprog for virksomhedsledelse ikke længere tilstrækkeligt. Derfor kræver en brug af hverdagens sprog, som er anderledes end det, der anvendes i de normale officielle præsentationer, som de kendes fra virksomheders hjemmesider og regnskaber.

Det kræver en anden form for opmærksomhed på hverdagen og det hverdagsagtige. Det almindeliges betydning for strategien skal kunne fanges i flugten og endevendes i en fælles dialog. Det betyder, at alle deltagere skal have plads til at fortælle om deres ledelseshverdag, så forestillinger om sammenhænge og forløb får plads $\mathrm{i}$ typer af fortællinger om og fra virksomhedernes dagligdag.

Endelig vil arbejdet med uformelle strategiske processer bære præg af, at det består af mange sammenhængende og usammenhængende hverdagsprocesser, som tilsammen kan ses som en fortløbende, men ofte modsætningsfyldt diskurs i virksomheden. En måde at karakterisere det på, er gennem udtrykket meshwork (Ingold 2000), som både dækker, at det er en sum af processer, der snor sig ind imellem hinanden, skaber forskellige spor og er i stadig bevægelse. 
Strategiske hverdagsprocesser trækker samtidig på virksomhedens historie, vaner, rutiner og erfaring og arbejder på at konstruere troværdige billeder af en i princippet ukendt fremtid. Dette princip om den ukendte strategiske fremtid blev i øvrigt med finanskrisen fra slutningen af 2008 til en barsk realitet for flertallet af virksomheder og deres ledere, noget der fik stor betydning for forskningsprocessen i StraWay-projektet.

Formål med at studere strategiske hverdagsprocesser er at komme tættere på en erkendelse af, hvad det er, virksomhedsledere går og gør, når de i hverdagen håndterer sådanne opgaver. Men det er samtidig en proces, der, for at processen lykkes, for den enkelte leder skal føre resultater med sig i form af en øget erkendelse og øget evne til håndtering af strategiske processer. Dette er ikke erkendelse, der i forsknings- eller i praksissammenhæng alene handler om strategi. Det er erkendelse og ny viden, der tillige knytter sig til, hvad der holder sammen på og udvikler en virksomhed som organisation.

\section{Metodik og paradigme}

En undersøgelse af strategiske ledelsesprocesser benytter information fra såvel kvalitative som kvantitative datakilder. Den trækker på de formelle kilder i form af regnskaber, budgetter, planer og kalkuler, der stilles til rådighed. Men når det handler om at producere viden om de processer, som trækker på erfaringer og intuition og på hverdagsbegivenheder, vil kvalitative kilder spille en afgørende rolle. Udgangspunktet er her, at undersøgelser med hovedvægten på kvalitative studier vil være nødvendige til forståelse af mange fænomener, hvor det ikke er muligt eller ikke hensigtsmæssigt at søge at kvantificere data. Det er en diskussion, som føres i mange metodebøger (se f.eks. Kvale 2000; Robson 2002; Carson, Gilmore, Perry \& Gronhaug 2005; Andersen 2008).

I vores optik anvendes kvalitative metoder ikke uden tilpasning til det paradigme, der danner baggrunden for et konkret forskningsprojekt. Den relation, der skal opbygges mellem metodik og paradigme, skal specificeres (Arbnor \& Bjerke 2009:22). Det hænger sammen med, at et paradigme i praksis definerer, hvad der er data, og hvorledes data skal tolkes. Det er et udgangspunkt for den metodik, der præsenteres her, at paradigmet farver metodikken, samtidig med at det konkrete undersøgelsesområde ikke kun påvirker udformningen af metodikken, men at paradigmet gennem metodikken samtidig lægger et undersøgelsesperspektiv ned over feltet.

For at komme lidt mere konkret ind på dette og samtidig præsentere metodikken kan det være formålstjenligt at beskrive forløbet af det nu afsluttede StraCon projekt, hvor en række forskere i 2005 startede med en idé om at undersøge strategi. Det handlede i første omgang om at foretage eksplorative studier af strategiske processer i virksomhedskontekst. Den idé opstod ud fra, at vore erfaringer sagde os, at specielt i små og mellemstore virksomheders praksis var en systematisk brug af strategiske modeller og procedurer ikke særligt anvendt. Når der fandt strategisk ledelse sted, så det ud til at være præget af lejlighedsvis og spontan aktivitet og ikke af systemer og regelmæssighed.

Det er ikke for hverken små eller store virksomheder noget principielt nyt. Det synspunkt har været bragt frem gennem mange år (Mintzberg 1978; Mintzberg 1994). Men det, som vi som forskere gerne ville, var at skabe en empirisk baseret viden om, hvad der så finder sted i de mindre virksomheder, når der sker ændringer $\mathrm{i}$ relationer mellem virksomhedens omgivelser, dens ressourcer og dens mål. Var det ændringer, der var helt styrede af markedet, af de vaner, der 
eksisterer i virksomheden, eller gennem ideer, der opstår i situationen hos virksomhedens ledelse? Den metodiske konklusion på dette var, at dette kun ville kunne undersøges i et relativt tæt samspil med ledere, der praktiserer strategi.

Involvering af praktikere i forskningsprocessen

At trække praktikere ind som samarbejdspartnere $\mathrm{i}$ forskningsprojekt er inden for bl.a. organisationsområdet langt fra noget nyt. Mange af de forestillinger, der i dag eksisterer omkring, hvorledes organisationer fungerer, er udviklet gennem casestudier i enkeltvirksomheder, og metodik til casestudier er beskrevet i mange metodebøger (f.eks.Yin 1989; Robson 2002; Andersen 2008). Imidlertid var ambitionen i StraCon en anden, idet virksomhedsledere skulle spille en mere betydende rolle i produktionen af data end i det traditionelle casestudium. Det hang sammen med vores forståelse af, at specielt i små og mellemstore virksomheder har ledelsen en meget afgørende, men noget usystematisk funktion $i$ arbejdet med strategi.

Lederne skulle trækkes ind ikke alene som "dataleverandører", men også som kontaktskabere og som fortolkere af fænomener på feltet. StraCon blev fra starten udviklet til, at der skulle skabes en stærk forbindelse fra felt til metodik. Men det blev stadig tydeligere gennem forløbene, at netop den måde, strategi blev håndteret på - ofte som svar på noget pludseligt opdukkende (emergerende, se f.eks. Mintzberg 1978) og gennem intuitive handlinger, kræver visse paradigmatiske overvejelser. Det handler om, hvorledes intuition og brug af opbygget erfaring kan forstås, når det praktiseres i strategiske ledelsesprocesser. Det kræver en aktiv indsats ikke kun fra forskere, men også fra de ledere, der deltager.

Det at trække ledere fra forskellige virksomheder ind i et sådant projekt, er ikke helt ligetil. Ledere vil ofte opfatte et sådant projektforløb og deres deltagelse ud fra et af to forskellige perspektiver. Det ene perspektiv er, at deres rolle i forskningsprocessen er tilsammen at udgøre en form for styreeller koordineringsgruppe, som monitorerer forløbet. Det andet perspektiv er, at projektet skal ses som en avanceret form for erfaringsopsamlingsgruppe. Men intentionen med StraCon-metodikken var noget helt tredje: en integration af disse to opgaver. Lederne skulle derfor både være aktive med deres egne strategiske problemstillinger, de skulle optræde som kontaktpersoner til deres virksomhed, og de skulle deltage som diskussionspartnere med de øvrige virksomhedsledere og forskerne.

Ideen til denne opbygning hentede inspiration fra flere kilder. Dels var det et forsøg på at bruge erfaringer fra flerårige aktiviteter i træning af ledere. Dels var det erfaringer, som var hentet fra undersøgelsen af organisatorisk læring, som var et flerårigt empirisk studium. Og dels var der inspiration fra aktionsforskning og action learning. StraCon-projektet hentede på den måde inspiration fra forskellige sider af organisationssociologien og lagde samtidig et pragmatisk udgangspunkt. Pragmatisk i den betydning, at vi sammen med de udvalgte ledere løbende søgte at udvikle et forløb, som så vidt muligt passede alle deltagere.

\section{Metodeudvikling i StraCon}

Første runde af StraCon projektet lagde ud under ret kontrollerede former. Vi inviterede fem ledere, vi kendte til, og som vi troede på var interesseret i at diskutere strategi, til at deltage i en række forskningsseminarer over en periode på otte måneder. De kom fra forskellige virksomheder og forpligtede sig til at møde op til denne række seminarer - $\mathrm{i}$ alt fem af cirka tre timers varighed. 
De skulle endvidere modtage en eller to af os forskere på deres virksomhed for en præsentation af virksomheden, interview og gennemlæsning af relevante strategipapirer. Vi skulle så på grundlag af denne besøgsrunde skrive en case fra hver virksomhed, som byggede på aktuelle strategiske problemstillinger. Hver case blev godkendt og derefter præsenteret af den enkelte leder og diskuteret af alle på seminarerne. Det første seminar blev brugt til at præsentere metodikken og præsentere vore syn på strategi. Det sidste seminar blev brugt til en teoretisk og praktisk afrunding med en form for evaluering.

Denne første sæson var en resultatmæssig succes i form af de informationer, der blev produceret $\mathrm{om}$, hvordan strategi tænkes og håndteres i de fem virksomheder, og i den interesse, de fem ledere viste. Vi fik materiale til spændende cases, som både indeholdt interessante forskningsproblemstillinger og i flere tilfælde blev til anonymiserede cases, som blev anvendt $\mathrm{i}$ undervisningen (se f. eks. Gelsing m.fl. 2008). Det førte til, at vi næste år startede en runde med seks ledere, som vi ikke på forhånd kendte, og som på vores foranledning var blevet kontaktet af en regional, midtjysk erhvervsfremmeinstitution. Det andet år forløb cirka efter samme skabelon som det første, og resultaterne var af samme type og kvalitet.

Dette førte til et forøget ambitionsniveau for det tredje år, idet der her ikke kun blev samlet en gruppe på fem ledere, hvoraf en var genganger fra andet år. Aftalen med lederne blev, at hver virksomhed kunne besøges af forskere flere gange. Formålet med det var at søge at følge strategiske processer mellem et halvt og trekvart år. Det skulle gøres for derigennem dels at følge udviklingen i det enkelte strategitema og dels at se på, hvorledes strategiske temaer afløser hinanden i virksomheder. Med det metodiske koncept skiftede undersøgelsen karakter.

$\mathrm{Nu}$ var der ikke længere tale om en traditionel eksplorativ undersøgelse, idet den nu i høj grad koncentrerede sig om proces og kommunikation omkring strategiske processer. Undersøgelsens paradigme var på vej til at forlade sit tidligere relative brede udgangspunkt, hvor økonomer, erhvervsøkonomer, organisationsteoretikere og ledelsesforskere ud fra hvert deres perspektiv skulle kunne udnytte data. I stedet blev undersøgelsen i stadig højere grad præget af en interesse for det intuitive og det erfaringsbaserede i strategisk ledelse og dermed i et forsøg på eksternalisering af erfaring og intuition til brug for forståelse af, hvorledes uformelle strategiske processer forløber.

Denne udvikling, hvis mere principielle rammer vil blive diskuteret nedenfor, var ikke kun påvirket af de strategiske temaer, der blev analyseret i cases og i seminarer mellem ledere og forskere. Den blev samtidig skabt af de ledere og forskere, der deltog. Lederne var ud over at være administrerende direktører eller næstledere en relativ heterogen gruppe, men med visse homogene kendetegn. Det første hold bestod af to økonomer og tre ingeniører, alle i fyrreårsalderen. Det andet hold var lidt mere heterogent med en lidt højere gennemsnitsalder og med halvdelen med en formel videregående udannelse og den anden halvdel uden. Med hensyn til den tredje runde var deltagerne to ingeniører, to økonomer og en med anden uddannelse. Virksomhederne arbejdede inden for en lang række brancher. Forskernes fagfelter var som nævnt tidligere: økonomi, organisation og ledelse. To forskere var gennemgående i alle tre forløb, mens tre deltog i et eller to forløb. 
Figur 1 StraCon-undersøgelsens forløb

\begin{tabular}{|l|l|l|l|l|l|l|}
\hline Forberedelse & 1. forløb & Efterbehandling & 2. forløb & Efterbehandling & 3.forløb & Efterbehandling \\
\hline Forskerne & 5 ledere & Forskerne & 6 ledere & Forskerne & $5^{4}$ ledere & Forskerne \\
\hline 6 måneder & 8 måneder & 4 måneder & 8 måneder & 4 måneder & 8 måneder & 6 måneder \\
\hline
\end{tabular}

De tre forløb kan retrospektivt ses som trin i en metodeudvikling. Første forløb blev en afklaring af, hvordan strategiarbejde i sådanne små og mellemstore virksomheder kan anskues. Andet forløb kom til at sætte fokus på lederes aktiviteter i sådanne forløb. Tredje forløb blev i betydelig grad rettet mod, hvorledes ledere kommunikerer mellem sig og med medarbejdere i forbindelse med strategiske processer i den enkelte virksomhed.

Specielt springet fra et besøg til flere i det tredje forløb, tre til fire besøg pr. virksomhed, betød samtidig et betydeligt tættere og integreret samspil mellem de forskellige forskningsaktiviteter: interview med lederen, interview med andre ledere i samme virksomhed, dokumentstudier og virksomhedsbesøg. I tre af de deltagende virksomheder i tredje forløb betød det en nærmere integration af forskere i den løbende diskussion af virksomhedens strategiske temaer. Kontakten til de to øvrige var mere formel. Som en sideeffekt af dette kom én af virksomhederne til ret intensivt at medvirke i et flerårigt ph.d.- projekt om strategisk ledelse, udvikling og kommunikation.

Sammenhænge mellem felt, paradigme og metodik

Principperne, som de er blevet udviklet i løbet af den samlede proces, kan ses i et samspil mellem felt, paradigme og metodik.

Figur 2 Felt, paradigme, metodik

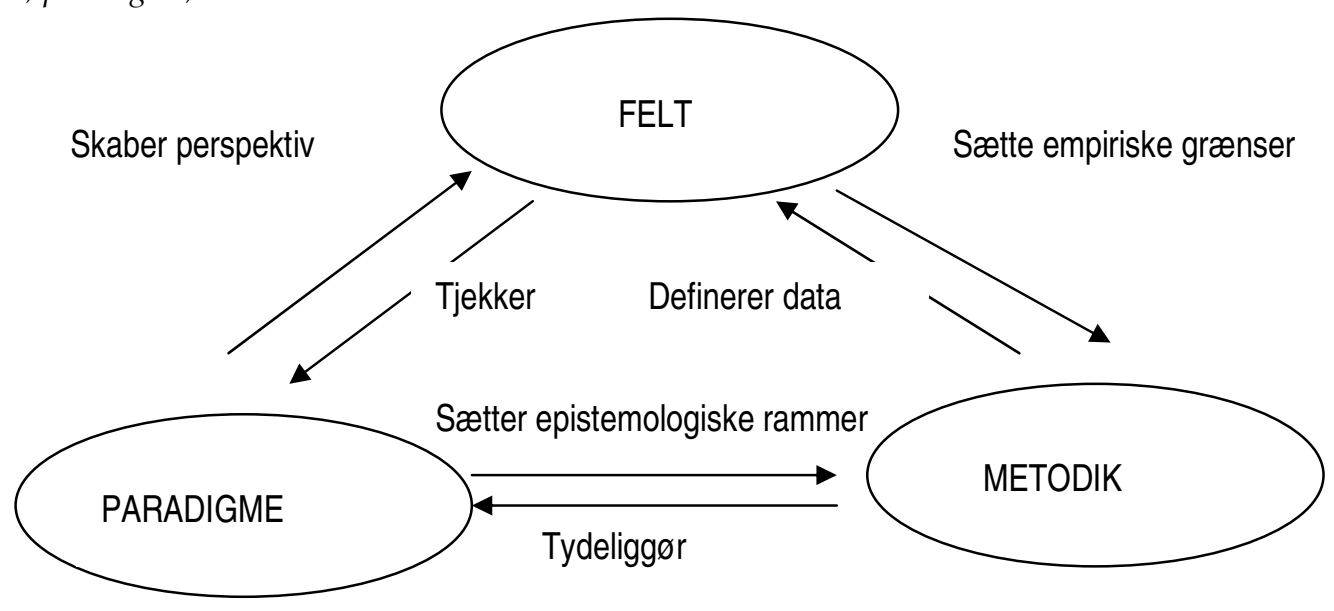

Principperne for undersøgelsen blev ud fra den måde, forskningstemaerne udviklede sig på, som nævnt stadig mere inspireret af et fortolkende paradigme. Det betød dels, at hvor det i starten var en eksplorativ undersøgelse af, hvor meget mainstream strategiteori blev brugt, og hvad der

${ }^{4}$ Heraf én genganger fra året før 
supplerede dette, så udviklede formålet sig til at se på, hvad det var, ledere med en omfattende praktisk og teoretisk uddannelse anvendte i strategiarbejdet, når det fra de første forløb kunne konstateres, at de ikke brugte de modeller, de havde lært om på læreanstalten og læst om i bøger. For at kunne komme nærmere ind på dette krævede det en metodik, der arbejder med relationerne mellem ledere indbyrdes og mellem ledere og forskere. En iagttagelse, der blev gjort, var, at lederne, når de var sammen, ikke talte om strategi i mainstream strategisprog, men meget mere var indstillet på at gøre det $\mathrm{i}$ det sprog, som de bruger $\mathrm{i}$ deres hverdagskommunikation $\mathrm{i}$ virksomheden.

Det sprog definerer en række empiriske grænser, som er med til at forme metodikken, når den arbejder under et fortolkende paradigme. Samtidig skaber et sådant paradigme et bestemt perspektiv på feltet og dermed på empirien. Dette kan forstås på den måde, at i metodikkens operationalisering af paradigmet sker der en tydeliggørelse af særlige karakteristika ved dette. Det betyder f.eks., at den samtale, der foregår mellem leder og forsker, føres af begge ud fra en interesse om, at de internaliserede erfaringer om strategi får en mulighed for at blive eksternaliseret gennem det hverdagssprog, der anvendes (se f.eks. Arbnor \& Bjerke 1977:139; se også Nonaka \& Takeuchi 1995). Det tydeliggjorde og prioriterede opmærksomheden på uformelle kommunikations- og fælles reflektionsprocesser. Det betyder endvidere, at dialogen mellem ledere og mellem ledere og forskere får et intensivt udforskende indhold på en anden og mere direkte virksomhedsrettet måde end den første fases eksplorative studier.

Dette retter den metodiske interesse mod den måde, strategiske processer skaber mening og betydning på, og de ledelsesprocesser, der knytter sig til dette. Som nævnt kan forskningsprocessen, som den blev udøvet i det tredje forløb, opfattes som en bestræbelse på eksternalisering af erfaringer, som gennem en længere periode ved brug er blevet internaliseret hos ledere, i gruppen af ledere i den enkelte virksomhed, og i et vist omfang i hele virksomheden og $i$ dele af dens omgivelser. Denne eksternalisering fremmes gennem en metodik, der såvel anvender en integreret kombination af dokumentstudier, virksomhedsbesøg, observation, ustrukturerende interview, etnografiske interview, samtaler, cases diskussioner og en fortløbende dialog.

Ledere og forskere medvirkede i processen som ligestillede parter, men med forskellige kompetencer. Sammen udforsker de processer, der ikke findes dokumenteret viden om, og hvor det, der måtte være nedfældet i rapporter ol. i virksomheden, kun omfatter en lille del og kun berører hjørner af det internaliserede og usagte.

\section{Metodikkens konceptuelle inspiration}

Et retrospektivt blik på metodens udvikling gennem de tre forløb åbner for et andet tema, som handler om, hvor de enkelte elementer i metodikken hentes fra. Metodikken blev udviklet, mens undersøgelsen fandt sted, og det gælder tillige videreudviklingen i StraWay-projektet, som har været i gang siden 2009. Denne udvikling prioriterede i høj grad metodikkens praktiske sider. Hvad angår den mere teoretiske side, er inspirationen mere indirekte, men den har tydeligvis elementer til fælles med tidligere anvendte metodikker i empiriske undersøgelser. Til gengæld vil det ikke være muligt alene at følge ét enkelt spor bagud for dermed at skabe et overblik over de teoretiske rødder for metodikken. 
En måde at se på de teoretiske rødder for undersøgelsen er at tage udgangspunkt i samtalen (Kvale 2000:47) som metodikkens "mindste" enhed for frembringelse og forståelse for de processer, der studeres. Dette peger på den inspiration fra fænomenologien, som metodikken er kommet til at bære præg af. Det er på flere måder studiet af en intentionel og kollektiv proces. På den måde eksisterer der relationer til Berger og Luckmann (Berger \& Luckmann 1976) og til Alfred Schutz (Schutz \& Luckmann 1973) og dermed til forestillingen om livsverden og dialektikken mellem samfund og menneske, og således her mellem virksomhed og leder. En central inspiration er i den sammenhæng to svenske aktørsforskere (Arbnor \& Bjerke 1977; Arbnor \& Bjerke 2009), som bl.a. kan stå som inspiratorerne til dialektikken mellem internalisering og eksternalisering i metodikken. Den samlede metodik, og herunder, at såvel kvantitative som kvalitative kilder og teknikker anvendes, bliver til det, som benævnes mixed, flexible method (Robson 2002). Det betyder, at feltet, og det forløb, erkendelse produceres gennem, styrer de operationelle beslutninger om anvendelse af enkeltteknikker. At metoden er mixed er lig med, at valget af dialogform afhænger af feltets øjeblikkelige respons. Et virksomhedsbesøg er planlagt til et bestemt sted på et aftalt tidspunkt, men alt efter hvad der sker på den dag i virksomheden, kan kredsen af samtalepartnere og formen for kommunikation fastlægges eller ændres på stedet.

\section{Inspiration fra Action Research}

Det tredje og mest sammenfattende niveau i undersøgelsen og dermed de roller, deltagerne og deres kommunikation får, er, set retrospektivt, inspireret af aktionsforskning og af action learning. Det var en erkendelse, der først sent er kommet eksplicit ind i arbejdet, men implicit har spillet en rolle hele tiden. Det hænger sammen med, at metodikken deler flere elementer med aktionsforskning (Dickens og Watkins, 1999). Det gælder åbenheden over for som forsker direkte at være med i de forandringsprocesser, som en eksplicitering af tavs strategisk viden i sig selv medfører, og vigtigheden af at lade ledere diskutere hinandens forståelse af strategi og strategisk ledelse. Man kan selvfølgelig sige, at al forskning er aktionsforskning (Mathisen 1973:31), men selv uden at gå til den yderlighed, er der aktionsforskningselementer i metodikken, dog uden, som det til tider gøres, at aktionsforskning først og fremmest er et forsøg på at realisere bestemte praktiske mål (op. cit.:31).

Det, som metodikken helst ikke deler med aktionsforskning, er risikoen for ubevidst at blive forført af bestemte ledelsesagendaer, mens vægten på refleksion (Clegg, Hardy \& Nord 1996:21) og samarbejde er prioriteret. Det betyder, at metodikken accepterer, at andre end forskerne direkte skal have et udbytte af arbejdet. Det er et princip i metodikken, at lederne enkeltvis og tilsammen kan handle for at nå egne mål. Det er i øvrigt noget, som direkte kan observeres i de fælles diskussioner på seminarerne. Lederne analyserer andres ideer, kommer selv med ideer til fælles overvejelse og med løsningsforslag på andre lederes problemer. Megen af den dialog, som finder sted på seminarerne, har til formål, at lederne hjælper hinanden til at nå nye erkendelser og konklusioner på konkrete strategiske problemstillinger. Fandt dette ikke sted på seminarerne, ville det være meget vanskeligt at fange og forstå dele af den implicitte erfaringsbaserede viden, den enkelte leder besidder. Det er igennem at arbejde på den måde, det implicitte i strategisk ledelse kommer frem i dialogen.

Det fører direkte ind i Kurt Lewin's arbejder med Action Research fra 1940erne, som ifølge Chris Argyris (French \& Bell 1999: 138) var: problemdrevet, klientcentreret, udfordrede status quo og producerede empiriske modfortællinger, som passer ind i en teori, der er brugelig i hverdagslivet. 
Flere af disse elementer ligger inden for den metodik, som præsenteres her, selv om modfortællingen ikke har spillet nogen rolle i metodikken indtil nu.

Metodikken er problemdrevet $\mathrm{i}$ et problembaseret læringsformat $\mathrm{i}$ arbejdet med at definere strategiske problemstillinger, og arbejdet med disse problemstillinger kan netop føre til eksplicitering af internaliserede erfaringer. Klientcentreret handler om, at dette også er til gavn for lederne. Udfordrende status quo handler om at se strategi som noget andet end mainstream lærebogsteori. Og brugelig teori handler om vægten på teori som hverdagsopfattelser og -sprog. Action Research set i Lewins perspektiv handler om, at hvis organisatoriske mønstre af relationer skal forstås, kan det kun ske gennem et forsøg på at ændre disse. Det er en forudsætning, som den her anvendte metodik søger at imødekomme gennem de fælles diskussioner af specifikke strategiske processer.

\section{Kobling til Action Learning}

En anden tilgang, som kan siges at have lighedspunkter med aktionsforskning, og som præger metodikken, er Action Learning 5 . Det er cirka 60 år siden, begrebet Action Learning (Revans 1992) blev præsenteret for ledelserne i en række engelske kulminer. Action Learning kan næppe siges siden da at være blevet en dominerende læringsmetode, men findes i en række versioner (Marsick \& O'Neal 1999). Pointen er imidlertid, at denne metode anvendt som et led i praktisk empirisk forskning kan bruges i en afklaring af, hvorledes den tavse viden, der har betydning i strategisk ledelse, kommer til veje. Det er samtidig således, at elementer af denne Action Learning kan genfindes i den måde, som strategisk ledelseskompetence opbygges på i praksis i virksomhederne, om end dette sjældent sker i en særlig systematisk form. Action Learning har i sit oprindelige udgangspunkt følgende praktiske spørgsmål til ledere:

- Hvad er det, jeg og min virksomhed virkelig forsøger at nå?

- Hvad stopper os i at nå det?

- Og kan vi finde en vej til at løse dette?

(Revans, 1992:67; min oversættelse JGR)

Selv om sådanne spørgsmål ikke var formuleret eksplicit i de tre forløb i StraCon, så var det temaer, der i høj grad prægede de diskussioner, der foregik på seminarerne, og det var tydeligt, at ledere i flere tilfælde tog ideer til nye løsninger med hjem. Dette knytter sig til forestillingen om at forstå gennem at skabe forandring, der er et led i selve metodikken. Det er i øvrigt en proces, der har været fremhævet af flere ledere i de evalueringer, der efter hver runde blev foretaget.

\section{Resultater fra StraCon}

Da denne artikel koncentrerer sig om at præsentere en forskningsmetodik, er der ikke plads til at præsentere de resultater, der er kommet ud af StraCon-projektet. Det er sket andre steder (Gelsing m.fl. 2008; Larsen \& Rasmussen 2008 B; Larsen 2008; Rasmussen 2008). En opsummering af dette vil være den vægt, der her har været lagt på at præsentere ligheder og forskelle mellem de resultater, StraCon-projektet har produceret, og så mainstream strategifremstillinger.

\footnotetext{
${ }^{5}$ Lighederne med Action Research blev genopfrisket gennem kommentarer fra professor Vernon Trafford, Anglia-Ruskin University, Cambridge, da han i vinteren 2010 blev præsenteret for metodikken.
} 
Et gennemgående resultat er, at blandt ledere af små og mellemstore virksomheder spiller de formelle teorier, modeller og teknikker en ubetydelig rolle. Hvad der derimod spiller en rolle, er den specifikke og særlige måde, hvorpå ledelsen i den enkelte virksomhed opfatter dens relationer til omgivelserne og de interne relationer. Et andet gennemgående resultat er, at set henover en enkelt sæson er der mange af de enkelte elementer i strategien, der skifter betydning. Men samtidig har ledelsen bag dette en forståelse af, at de udvikler og fastholder en implicit kerne af strategi i virksomheden, som set $\mathrm{i}$ deres tidsperspektiv er næsten uendelig og som i meget høj grad indeholder billedet af, hvad virksomheden er, kan og skal.

\section{Metodikkens elementer og praktiske fremgangsmåde}

Det har ovenfor været nævnt, hvilke elementer metodikken er bygget sammen af: besøg, cases, seminarer og efterbehandling. Imidlertid kan metodikken beskrives mere detaljeret i følgende elementer: Udvælgelse og introduktion af aktører, undersøgelser i virksomheden, udformning af case, præsentation af case, diskussion af case med deltagelse af ledere og forskere, opsamling af resultater og ny runde af undersøgelser. Denne grundform blev udviklet til den tredje runde af StraCon projektet og anvendes i det igangværende StraWay-projekt (Larsen \& Rasmussen 2009).

Generelt kan det siges, at forskning inden for strategi og tilgrænsende områder er præget af et paradoks mellem på den ene side alle de fine og afslebne teorier og modeller, og på den anden side al det "rodede" meshwork praksis. Det er et paradoks, der er flere "løsninger" på. En er at afskærme sig fra rodet gennem at afgrænse sin forskningsaktivitet til det, der kan kontrolleres, hvilket i høj grad er simplificerede modeller, som kun tager virkeligheden op under ordnede former. En anden løsning er som virksomhedsleder at acceptere at befinde sig midt i meshworket og søge at løse problemerne, som de kommer, måske engang imellem ved brug af dele af en model fra den "teoretisk ordnede" verden.

Og en tredje, som er den, der følges her, og som kan vise sig at være den mest vanskelige, er at søge at afklare nogle af disse dynamiske forløb som meshwork gennem en fælles indsat mellem ledere og forskere. Det er den måde, som har brug for kvalitative metoder til gennem dialog at sætte betydning på det uklare og utydelige. Men det er som nævnt ikke den måde, lederne lærte om strategi, da de for år tilbage gik på læreanstalterne. Og det er næppe den måde, de over for omverden ville præsentere deres arbejde med virksomhedens strategi. Med andre ord skal den samlede undersøgelsesproces indeholde en form for anonymt og eksperimentelt frirum for lederne.

\section{Samarbejde mellem virksomhedsledere og forskere}

Et spændende og samtidig forstyrrende aspekt ved dette er, at ledere og forskere ofte ser den anden part som kommende fra en anden planet. En forudsætning for et vellykket projekt ved anvendelsen af en kvalitativ metodik i den her beskrevne form er imidlertid ikke at søge fra starten at gøre alle deltagere ens eller at skabe et ensartet sprog, som alle kan anvende. Det ville nemlig, hvis det kunne lykkes, føre til en sproglig og indholdsmæssig forarmelse.

Det, som har vist sig, ikke er umuligt at skabe i undersøgelsesprocessen, er en accept af forskellighed i opfattelser og fortolkninger og en vilje til at bruge denne forskellighed til en mere dynamisk og dybtgående forståelse af fænomenet strategisk ledelse i hverdagen. Det kræver imidlertid en fælles diskussion mellem ledere og forskere om to former for indsats. Den ene er fra starten at involvere lederne i udformning af cases og præsentation af disse. Den anden er, at 
forskerne fra starten gør deres indlæg prøvende, spørgende og åbne. Centralt i denne metodik er at gøre alle til ligeværdige deltagere i dialogen på virksomheden og på seminarerne.

Figur 4 Undersøgelsens praktiske forløb (et gennemløb)

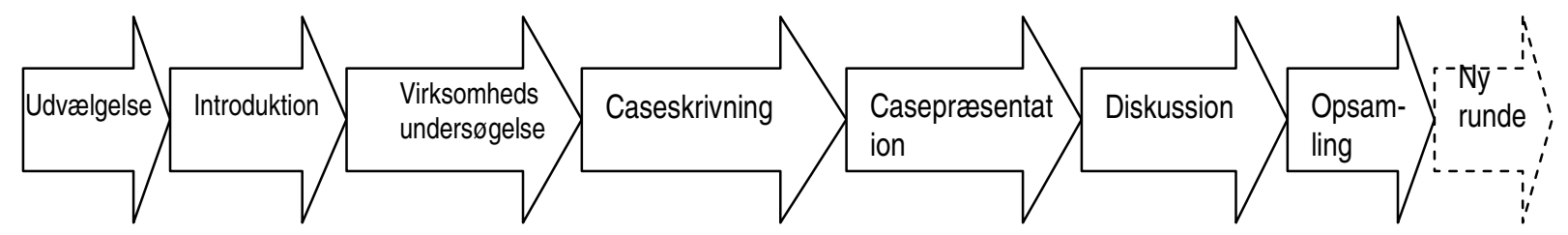

Udvelgelse og introduktion af aktører

Den udvælgelse, som er blevet brugt, har rettet sig mod at involvere ledere, der af sig selv er interesseret i temaet strategisk ledelse. Hvad der kan ses som afgørende i de første faser, er den introduktion, som lederne får om undersøgelsens karakter og formål. Metodikken kan ikke præsenteres som beskrivende eller hypoteseprøvende, hvilket ofte vil være lederes forventning til et forskningsprojekt. Den beskrives som en søgen for at komme "bagom" den måde, strategiske processer og strukturer normalt præsenteres formelt og officielt, og ind til ledernes daglige aktiviteter på området. Det er et afgørende punkt, idet fænomenet, der undersøges, både er et, lederne har daglig kontakt til, men samtidig er det et, som mange teorier og modeller kun beskriver i formaliserede termer. Et formål med introduktionen er, at aktørerne kommer frem til en erkendelse af, at dette er en analyse af deres og deres virksomheds hverdagspraksis, og det er ikke er recitation af de mest gængse teorier på markedet.

Hvis reaktionen fra aktørerne over for forskeres præsentation af metodikken ikke i starten lyder noget i retning af: "Hvad er dette for noget?", så er sammenhængen mellem paradigme og metodik sandsynligvis ikke udtrykt tydeligt nok, idet den valgte fremgangsmåde vil virke særegen for langt de fleste ledere. Processen har hverken form som en forelæsning på læreanstalten eller som et møde $i$ en VL- (virksomhedsledelses-)gruppe. Men hvis denne reaktion til gengæld ikke i løbet af det første seminar ændrer sig til en, der er præget af større indsigt i metodikken, risikerer lederen at blive inaktiv.

Denne problemstilling er ikke enkel at håndtere. Det hænger sammen med mange lederes forudfattede syn på forskning, som, hvilket var tydeligt i starten hos flere ledere i StraConprojektet, går i retning af, at forskere er typer, der kommer med abstrakt afprøvede teorier og modeller, som et givet begivenhedsforløb fra praksis skal prøves over for. Forskere kan ikke i lederes normalperspektiv være personer, der i bund og grund er mest interesseret i praksis. Hvis forskerne derfor lægger ud med, at det, som skal i centrum, er strategisk praksis, vil det af nogle ledere blive opfattet som noget ret fremmedartet.

Dette var specielt i forbindelse med den første kommunikation både i StraCon- og i StraWayprojektet lidt overraskende for flere af de ledere, der havde meldt sig, men efter at de gennem seminarerne havde vænnet sig til det, skabte det en forestilling om, at alle - aktører og forskere var uens, men ligestillede, og at det var et fælles ansvar for alle at bidrage med den viden og de erfaringer, de kunne. De centrale punkter i introduktionen inkluderer fra forskernes side på den måde at vise, at der kan skabes relationer mellem undersøgelsens formål og de traditionelle teorier, 
men at undersøgelsen er opbygget med den intention at komme ind under de formelle modellers og teoriers generelle og abstrakte kommunikation for på den måde at få forståelse af, hvad der foregår i hverdagen.

Pointen for både aktører og forskere er, at projektet indledende skal ses som en udveksling af erfaringer og viden på området mellem forskere og ledere og indbyrdes mellem lederne. Men projektets metodik indeholder en betydeligt mere krævende ambition i form af en fælles produktion af viden om det internaliserede. Det kræver en del af forskernes præsentation af metodikken. Det hænger sammen med, at der på den ene side er risiko for, at processen kan udvikle sig til en traditionel erfaringsudveksling mellem lederne. En proces, som næppe fører til megen ny erkendelse. Eller at konteksten i stedet udvikler sig til en ramme for "akademisering" / kategorisering af hverdagsviden. En proces, som heller ikke er hensigtsmæssig. Derfor er en del af det fokus, metodikken skal sikre, rettet mod opbygning af en fælles kontekst, der så vidt muligt ligestiller aktører og forskere.

Forskerne præsenterer metodikken og viser derigennem interesse i, at den enkelte aktør både får kommentarer og - viser det sig - gode råd fra de andre aktører. Det skal tillige give mulighed for at få de strategiske problemstillinger, der dukkede op fra praksis, kommenteret gennem forskernes viden om teorier, modeller og generelle opfattelser på feltet og tilgrænsende felter (organisation, kommunikation, netværk, driftsøkonomi mv.). På den anden side skal processen gennem sine undersøgelser af strategi i den enkelte organisation via casene, de fælles diskussioner og opsamlinger bidrage til, at forskerne får et materiale til deres videre analysearbejde. Projektet er hverken et traditionelt uddannelses- eller udviklingsseminar for ledere eller en traditionel interviewundersøgelse, men en syntese af sådanne aktiviteter.

Det sidste er ikke mindst væsentligt for at få den afsluttende del af introduktionen af undersøgelsen over for lederne til at falde på plads. Det er den del, der handler om, at en sådan undersøgelse ikke kan fungere, uden at forskerne får adgang til at besøge og undersøge den enkelte virksomhed for på den måde at skabe den information, der muliggør en diskussion af fænomenet strategi, som det udfolder sig i praksis. Det er selve kernen i metodikken, og det kræver en udstrakt åbenhed fra den enkelte leder, men det kræver i lige så høj grad, at forskerne giver lederen udstrakte muligheder for at styre, hvad der kommer frem.

Det vil blive berørt i det følgende, men det skal allerede her understreges, at dette ikke kun indeholder en etisk problemstilling, men også er en forudsætning for, at lederen i det hele taget har mulighed for at være åben inden for disse rammer. Endelig lægger ikke bare introduktionen, men også den foregående invitation til at deltage, afgørende vægt på, at al information, som kommer uden for aktørernes og forskernes kreds, er anonym, og diskussioner og data er så fortrolige, som den enkelte leder ønsker. Det er en vigtig del af den "kontrakt", der tegnes ved det første møde mellem ledere og forskere.

\section{Undersøgelse i organisationer}

To forskere - eller i enkelte tilfælde en enkelt forsker - står for at aftale med den enkelte leder om, hvornår og hvordan vedkommendes virksomhed skal besøges. Formålet med dette første besøg er dels at få et overordnet billede af virksomheden og dels at komme i dybden med den måde, virksomheden og dens ledelse beskriver og tackler de strategiske problemstillinger, der aktuelt og 
dermed i øjeblikket vise sig betydningsfulde for dem. Forskerne møder efter aftale op i virksomheden - og mere præcist startes på lederens kontor for en indledende snak om virksomheden, dens strategiske situation og aktuelle strategiske problemstillinger.

Forberedelsen af denne snak foregår gennem, at forskerne har kigget i regnskaber, årsberetninger og på virksomhedens hjemmeside og eventuelt før mødet har modtaget dokumenter fra lederen. Men en pointe er, at denne forberedelse ikke må strukturere samtalen så meget, at det ender med en traditionel beskrivelse af de formelle procedurer i organisationen. Der skal i stedet være rigelig plads til, at lederen fortæller sin(e) version(er) af historien. En fortælling, som på samme eller senere besøg bliver suppleret med tilsvarende fortællinger fra andre ledere i virksomheden. Den form for samtale, der er blevet udviklet til StraWay-undersøgelsen, ligger tæt på et ustruktureret, kvalitativt interview med vægt på forskerens understøttelse af, at lederen fortæller sin og virksomhedens historie.

Når der lægges vægt på, at besøget skal bruge sådanne personbårne fortællinger som startpunkt, hænger det sammen med, at det ikke er i undersøgelsens og heller ikke i deltagernes interesse at få gentaget de formaliserede fortællinger, der allerede er offentliggjort på virksomhedens hjemmeside, i nyhedsmedier og lignende steder. Et formål med metodikker er ved hjælp af ledernes "gentænkning" af hverdagens aktiviteter at nå nye erkendelser omkring strategipraksis.

Figur 4 Forløbet af et første besøg $i$ en virksomhed

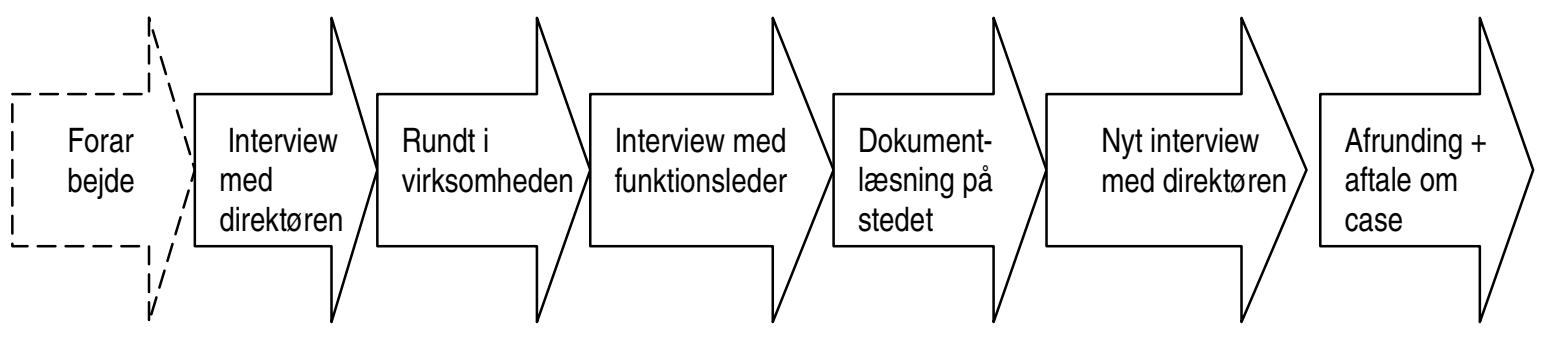

Besøget i organisationen annonceres af den medvirkende leder til dem, vedkommende finder det relevant for. Det hænger sammen med, at det hele tiden er lederen, der styrer forløbet af besøget. Lederen er knudepunktet både som medvirkende i produktionen af data og senere som modtager af disse data i en bearbejdet form. Det har som en del af metodikken vist sig hensigtsmæssigt, om lederen bruger tid på det første besøg til en rundvisning af forskerne til de dele af organisationen, som lederen mener, er de centrale i en strategisk sammenhæng. Væsentligt er her i øvrigt, at lederen benytter lejligheden til at give sin beskrivelse og analyse af strategiske problemstillinger i forbindelse med en sådan rundvisning. Erfaringer viser, at det giver en levende fortælling, som knytter strategi til praktiske opgaver og problemstillinger i virksomheden.

Lederen er som nævnt den centrale aktør i projektet, og det er i den sammenhæng vigtigt for forskerne at søge at komme i en detaljeret dialog med lederen om, hvordan vedkommende selv ser virksomheden håndtere strategiske problemstillinger i hverdagen. Det kan være alt fra pludseligt opstående problemer og muligheder, som viser sig at få strategisk betydning, til de procedurer, ved hjælp af hvilke virksomheden mere langsigtet søger at styre strategiske processer. Her sættes ord 
på og samtidig skaffes, hovedsageligt på lederens initiativ, såvel officielle som mere uofficielle dokumenter frem af betydning for forståelsen af den strategiske situation. Der tegnes sideløbende et billede af, hvilke andre aktører i virksomheden der efter lederen opfattelse er centrale $\mathrm{i}$ håndtering af strategien. Specielt hvad det sidste punkt angår, kan forskerne alt efter lederens planlægning af besøget under dette kontakte nogle af disse aktører - hvis de har tid - eller gemme oplysninger om deres navne, placering og funktion til brug for kontakt før senere besøg.

Hovedopgaven ved besøget er, at forskerne får datamateriale til at skrive en case, som via information om virksomhedens aktuelle strategiske situation tegner et billede af centrale strategiske problemstillinger. Besøget får en afgørende betydning i den sammenhæng, hvorfor det i nogle tilfælde er hensigtsmæssigt at optage væsentlige dele af dialogen, eller, hvis lederen foretrækker det, at forskerne under og umiddelbart efter besøget noterer deres iagttagelser. Vigtigheden af dette hænger sammen med, at det er forskerne, der alene samler dokumentationsmaterialet og sammen foretager den første analyse af dette, og først i næste fase involveres lederen direkte i færdigskrivningen af casen.

\section{Udformning af case}

Casebeskrivelsen af virksomhedens strategiske problemstillinger er det helt afgørende redskab i kommunikationen mellem lederne og mellem lederne og forskere, idet det er det dokument, som alle har foran sig på de seminarer, der har som formål at få belyst og gennemdiskuteret strategiske vanskeligheder og muligheder. En casebeskrivelse er i den sammenhæng et dokument på $3-6$ sider og udgør resultatet af en fælles første analyse af kvalitative data - normalt også med baggrund i kvantitative data fra regnskaber, budgetter, beretninger og økonomiske kalkuler.

Pointen i udformningen af casebeskrivelsen er, at organisationens strategiske problemstillinger ses gennem to linser på én gang: forskerens og lederens, men at det er forskeren, der på grundlag af de indsamlede data skriver en skitse til casen, som derefter e-mailes til lederen, som kommenterer og korrigerer denne. Denne fremgangsmåde er valgt for, at det på den måde bliver muligt på en gang at fastholde lederens erfaringsgrundlag og via forskernes virksomhedsbesøg at få nye perspektiver ind til inspiration for den erkendelsesproces, der i bund og grund er lederens. Derfor skal lederens arbejde med disse korrektioner ikke ses som en udskiftning af en række fakta med andre, men skal i stedet bruges som en refleksion fra lederen over forskerens forståelse af de bagvedliggende data. Denne proces løber i flere tilfælde over flere trin, hvor forsker og ledere kommunikerer med hinanden om casens udformning og vægtning af dens forskellige delemner. Nogle ledere er i denne proces ret aktive med at komme med nye ideer og andre tolkninger, mens andre mere ser opgaven som en traditionel ledelsesmæssig godkendelse.

Den første case skal behandle organisationens strategiske situation og knytte den til væsentlige karakteristika ved organisationen og dens omgivelser. Samtidig må den gerne munde ud i nogle strategiske temaer, som lederen ønsker at få taget op til diskussion på seminaret for på den måde at få alternative tolkninger udøvet af eksperterne, som her er de andre ledere uden forudgående kendskab til virksomheden. På den måde understreges lederens afgørende betydning i udformningen af casen samtidig med, at det er forskerne, der har det væsentligste ansvar for strukturering af casebeskrivelsen og for, at casen kan forstås uden for kredsen af organisationens egne ledere og medarbejdere. 
Casen sendes til de øvrige ledere og til de øvrige forskere, der deltager i projektet. Dette skal ske relativ kort tid før det næste seminar, for at alle på den måde kan tænke over de mere åbenlyse strategiske spørgsmål i casen. Samtidig er det klart, at også dette casedokument er fortroligt og ikke spredes ud over dem, der deltager i dette seminar.

\section{Præsentation af case}

Den godkendte case spiller som nævnt en afgørende rolle i den fortsatte produktion af data og dermed i udviklingen af en fælles baggrund til diskussionen af den konkrete strategiske situation $\mathrm{i}$ virksomheden og som bidrag til en mere almen forståelse af, hvordan strategiske processer fungerer som ledelsespraksis. Pointen er, at udformningen af casen sker i et samspil mellem leder og forskere, men at den samtidig kun er ét indspark i den forsatte fælles bestræbelse på at kunne forstå fænomenet: hverdagens strategiske processer og brug af ledelseserfaringer. Af den grund er det lederens privilegium at præsentere casen for de øvrige aktører og forskerne. Privilegium på den måde, at lederen dermed er i stand til at sætte en tydelig mundtlig accent på den skriftlige case. En accent, der kommer til at præsentere lederens overvejelser på grundlag af den produktionsproces, vedkommende har været involveret $i$ omkring omformningen af data fra organisationen til selve casebeskrivelsen.

Denne præsentation er samtidig en måde at fastholde den enkelte leders engagement i processen og vil give en vinkel på fænomenet, der vil være tættere på praksis og mere dybtgående end en præsentation foretaget af forskeren. Dette virker samtidig motiverende på de andre aktører, idet de herved får præsentationen fra den person, de mener, skal stå i første række i strategiprocessen. Det er tillige en person, der deler arbejdsverden med dem selv, og det er en person, der kan bruge hjælp til at løse praktiske strategiproblemer. Denne form for præsentation har dermed til formål ikke bare at fastholde "autentiske" billeder fra organisationen, men har tillige til formål at fastholde aktørernes aktive rolle $i$ analysen af strategiske problemstillinger.

Det er op til lederen at vælge præsentationsform, og det har været gældende for det store flertal af de cases, der har været præsenteret, at lederne i den første casepræsentation ofte starter med et overordnet billede af virksomheden - af og til hjulpet af et slideshow med forskellige illustrationer af organisationen, dens aktiviteter og aktører. De mest vellykkede præsentationer har imidlertid været dem, der er gået mest direkte til sagen: de specifikke strategiske problemstillinger. Sådanne præsentationer har muliggjort, at den efterfølgende diskussion har kunnet holde kursen direkte på en strategisk linje, samtidig med at lederen har fået mulighed for at holde diskussionen fast på, hvad der interesserer vedkommende. En anden væsentlig erfaring er her, at et mundtligt oplæg på cirka femten minutter giver en tilstrækkelig tydelig platform for den efterfølgende diskussion og analyse.

Kombinationen af casen og det mundtlige oplæg fra lederen er vigtig for den efterfølgende diskussion. Det gør det muligt at lade lederen have store frihedsgrader i det mundtlige oplæg. Dette har betydet, at nogle oplæg har været koncentreret om at give et historisk indblik i, hvorfor virksomhedens strategiske situation er, som casen viser. I andre tilfælde har det mundtlige lagt vægt på at beskrive de forandringer, der er sket mellem tidspunktet for skrivning af casen og tidspunktet for seminaret. Pointen ved frihedsgraderne er netop, at lederen på den måde kan søge at påvirke temaerne for den følgende diskussion, men samtidig er caseteksten en form for ramme for disse frihedsgrader. En pointe er tillige, at dette giver de øvrige deltagere en række 
frihedsgrader til at tolke case og præsentation på helt andre måder ud fra det erfaringsgrundlag, de har.

\section{Diskussion på seminaret}

Casebeskrivelsen og præsentation af casen er først og fremmest et redskab til gennem diskussion mellem ledere - og forskere at få endevendt en række dagligdags strategiske problemstillinger. Det kan f.eks. handle om outsourcing, indsats på nye markeder, problematiske salgskanaler, sammenbrud af centrale markeder, finansieringsproblemer, overordnede kompetenceudviklingsudfordringer, eller omstrukturering af organisationen. En diskussion af sådanne emner skal kunne løbe ad de veje, som lederne ønsker. Det hænger sammen med, at det er gennem diskussion og afprøvning af praktiske løsningsforslag fra de forskellige ledere, billeder dannes af, hvad strategiske processer i praksis går ud på.

Det er en diskussion, som lederne kan lade løbe frit, og forskernes indsats går mest på at spørge og at sørge for, at diskussionen ikke kommer for langt ud på sidespor i forhold til det strategiske emne. Det kunne ske, hvis én eller flere af lederne går i gang med at definere og løse problemer, som kun i ringe grad ligger inden for den fælles forståelse af, hvad strategi er, f.eks. rene operative personaleproblemer.

Disse diskussioner skal løbe frit for på den måde at få flere tolkninger af en præsenteret problemstilling frem. Alle strategiske problemstillinger har visse ligheder med andre strategiske problemstillinger, og det er i ligheder, men måske mere i forståelsen af forskelle, at en dybere forståelse af, hvad det er, der arbejdes med, opstår. Et samlet indtryk af dette er, at når diskussionen løber, så er henvisninger til standardstrategiteori og -opfattelser tilsyneladende helt trængt i baggrunden. I stedet er det aktørernes hverdagsteorier, der kommer frem. Med hverdagsteorier menes her problemforståelser og handlingsanvisninger, der bygger på praktisk erfaringer.

Diskussionen bliver på den måde en form for afprøvning af forskellige vinkler på problemstillingerne, men tillige de øvrige lederes afprøvning af løsningsforslag. Det betyder, at mange indspil i diskussionen kan blive hængende "i luften", idet ledere generelt accepterer, at deres analyse og deres forslag til løsning ikke på nogen måde kan blive den endelige løsning for den leder, hvis virksomhed er i centrum, men skal være inspiration til vedkommende. Dette gælder tillige forskerens mere spørgende input.

\section{Skriftlig og mundtlig opsamling}

En passende længde for en præsentation og efterfølgende diskussion er vanskelig at definere. I de fleste tilfælde kan en sådan diskussion fortsætte over længere tid, hvilket ofte viser sig gennem, at den fortsætter ind i den pause, der normalt er fastsat, før den næste case diskuteres. Derfor er det den overordnede tidsramme, der afgør den længde i tid, hver enkelt præsentation og diskussion skal have, men op mod en time kan være, hvad der pr. case maksimalt er tid til på et seminar. Den samlede længde for et seminar har efterhånden udviklet sig til fire timer. For at dette bliver overholdt, kræver det, at en forsker under seminaret styrer det overordnede tidsforbrug, mens en anden samler op. 
Det er væsentligt, idet formålet er at opsamle ideer, billeder og fælles analyseresultater fra diskussionen. Det kan være en vanskelig opgave for den eller de forskere, der er udpeget til det, idet det kræver en betydelig koncentration under seminaret, der ikke for vedkommende tillader nogen særlig aktiv deltagelse i diskussionen. Præsentation af en sådan opsamling skal ikke foretages efter hver case, idet dette i for høj grad kan blive en repetition af diskussionen. Det skal i stedet ske i det sidste kvarter af et seminar, hvor tre eller fire cases har været præsenteret og diskuteret. Det er en opgave, der som nævnt kræver en særlig evne til at opsamle og transformere resultater fra en diskussion af enkelttilfælde til en form for problematisering, der går på tværs af de enkelte diskussioner.

Selv om denne opsamling selvfølgelig kan støttes gennem notetagning fra seminarets dialoger, kræver det en koncentreret indsat på seminaret at få en opsamling til at virke succesfuld. Det hænger sammen med, at en sådan opsamling ved afslutning af et seminar ikke kun er en opsummering, men også bliver en form for delkonklusion, som skal motivere alle deltagere - ledere som forskere - til løbende at overveje, hvordan ledere og medarbejdere tackler strategiske problemstillinger. En væsentlig styrke ved denne form for forskningsproces er, hvis den også kommer til at virke mellem seminarerne.

\section{Løbende evaluering}

For at denne proces kan blive vellykket, skal seminarerne og deres afrunding samtidig kunne løse en anden opgave. Den er, at deltagelse i en række seminarer for travle ledere fra deres side kræver en prioritering af denne aktivitet. Og en prioritering kræver, at aktiviteten opfattes som givende og betydningsfuld. Dette peger igen på vigtigheden af, at ledere og forskere i fællesskab arbejder for at skabe en kontekst og et normsæt, så alle interesser er ligestillede, og alle parter arbejder i fællesskab for at opfylde deres forskellige erkendelsesbehov.

Denne kontekst dannes via den måde, samtaler føres om, hvad det er for et projekt, og hvilke krav deltagerne kan stille til hinanden og skal stille til sig selv. Men det handler også om noget så prosaisk som den lokalitet, hvor seminarerne foregår. Der har været eksperimenteret med dette over det samlede projektforløb i StraCon og StraWay, hvor universitetet, en erhvervsfremmeinstitution, en brancheorganisation og i flere tilfælde en af de deltagende virksomheder har lagt lokaler til. Det er tydeligt, at forventningerne og dermed konteksten er forskellig, om lederne er på fremmed grund i et universitet, eller om de er på hjemmebane i en af virksomhederne. Hjemmebanen kan skabe en større opgave for forskerne med at holde fokus, mens udebanen hos ledere kan skabe nogle særlige forventninger om formalisering.

I nogle af de evaluerende diskussioner, der er foregået, er der tre typer af vurderinger fra ledere, som er karakteristiske. Den ene er en udtalelse i retning af: "I begyndelsen var jeg ret skeptisk over for, om jeg kunne få noget udbytte af at deltage i dette". En anden går på følgende vis: "Jeg er blevet overrasket over, hvor mange praktiske forhold vi får diskuteret i en proces, jeg troede var præget af teoretiseren". En tredje gå i retning af: "Hvis jeg ikke var startet på dette forløb, ville jeg aldrig have taget mig tid til at løse dette, og jeg kan nu se væsentlige strategiske problemer $\mathrm{i}$ organisationen". Opsummeret kan det siges, at lederne får et udbytte af disse analyser og diskussioner, ellers ville deres sparsomme tid næppe blive brugt af dem til over et længere forløb at deltage i sådanne seminarer. Hvad forskerne får af udbytte, må nærmest måles i, hvilke nye erkendelser de er i stand til at skrive om og publicere. 
Opsamlingens afgørende betydning handler om at holde sig på sporet og vedligeholde motivationen - og gerne udbrede den til også at omfatte arbejdet i perioderne mellem projektets formelle aktiviteter. Det hænger sammen med, at alle - såvel aktører som forskere - reelt kun er bundet til processen gennem deres motivation og en opbygget følelse af forpligtelse. En måde at understøtte dette på er gennem nogle dage efter et seminar at sende en skriftlig opsummering af resultaterne til aktørerne, og at huske allerede på seminaret at aftale tidspunkter for de næste virksomhedsbesøg og det næste seminar. Det skal bemærkes, at i løbet af de tre StraCon-forløb og det StraWay-forløb, der er i gang, har ingen ledere forladt processen, til gengæld har ikke alle været lige aktive mellem seminarerne.

\section{De folgende runder}

Som det blev nævnt, var den eksplorative fase i de to første år af StraCon-projektet bygget op omkring ét besøg i hver virksomhed og én casebeskrivelse pr. virksomhed, men i den tredje sæson blev dette udvidet for at følge strategiske processer gennem flere besøg og seminarer. Dette førte i øvrigt til, som et sideskud på StraCon-projektet, at to af de involverede organisationers strategiske arbejde $\mathrm{i}$ praksis blev fulgt $\mathrm{i}$ over to år henholdsvis flere år (se f.eks. Larsen 2008). Det har medvirket til at reorganisere metodikken på en måde, så løbende besøg i StraWay-projektet er blevet en del af metodikken, og med de praktiske konsekvenser, at ledere og deres organisationer følges og inddrages i en flerårig periode.

Denne ændring i metodikken sker som følge af, at formålet med forskningsprojektet forandres. Hvor StraCon fra begyndelsen som nævnt var lagt an som et eksplorativt projekt, der skulle kunne producere data til forskere med forskellige paradigmatisk udgangspunkter, arbejder det igangværende StraWay-projekt ud fra en tilgang, hvor forbindelsen mellem et fortolkende paradigme og metodikken er tættere. Overgangen fra en til flere cases pr. organisation og vægtningen af at arbejde med en forløbsundersøgelse er en forudsætning for dette. Som det vil blive præsenteret i det følgende, er StraWay-projektet, mens dette skrives, i gang med sin fjerde runde.

\section{StraWay-projektets konkrete forløb}

Som beskrevet i indledningen har denne artikel ikke kun som formål at beskrive en metodik, der allerede har været bragt $\mathrm{i}$ anvendelse, men tillige at diskutere nogle metodiske problemstillinger, der viser sig i det igangværende StraWay-forskningsprojekt. Det vil blive gjort i dette afsnit startende med en kort præsentation af elementer i dette projekt og ligheder og forskelle til det tidligere StraCon-projekt.

Intentionen med at starte et nyt projekt var for de to forskere (Mette Vinther Larsen og Jørgen Gulddahl Rasmussen) ultimo 2008 at prøve at sætte særligt fokus på netop de processer, der udvikler de internaliserede, erfaringsbaserede, strategiske ledelseskompetencer. Dette skulle gøres gennem over længere tid at følge den kommunikation om strategi og de refleksioner, en udbygget udgave af metodikken ville muliggøre. Vi havde i forvejen kontakt til en brancheorganisation, der viste sig interesseret $i$ at skaffe deltagere til, hvad organisationens ledelse så som en udvikling af strategisk ledelseskompetence, og dermed noget, som derfor var i branchens interesse. De sendte i forsommeren 2009 gennem deres kommunikationskanaler vores invitation ud til deres medlemmer, og da fem direktører fra virksomheder inden for branchen havde meldt sig, blev projektet igangsat. 


\section{De deltagende ledere og deres virksomheder}

Medvirkede var lederne, tre mænd og to kvinder, for tre mellemstore og to mindre virksomheder. Imidlertid skete der det dagen før startseminaret, at lederen fra en af de mindre måtte melde fra, idet hendes virksomhed samme dag var gået i betalingsstandsning. Det medførte, at deltagerne i projektet er fire ledere og to forskere. De fire virksomheder har en række ensartede karakteristika. De er medlemmer af samme brancheorganisation, de har alle deres hovedsæder placeret $\mathrm{i}$ Danmark, de sælger alle på det danske og europæiske markeder, og ingen af dem sælger til konsumenter, men $\mathrm{B} 2 \mathrm{~B}$, og de har alle udbyggede design- og produktudviklingsfunktioner, der spiller en afgørende, strategisk rolle. De adskiller sig ved, at selv om råvarerne er ret ensartede, så er deres produkter ikke i konkurrence med hinanden. En af virksomhederne står selv for produktionen, mens de andre tre får produktionen udført i Asien og Østeuropa. To af virksomhederne har kunder globalt, mens de to andre to begge sælger på europæiske markeder. Tre af virksomhederne er ret kraftigt ramt af den økonomiske krise, mens den fjerde stort set har undgået dens virkninger.

Nøglepersonerne i projektet er de fire ledere, hvoraf to har meget omfattende ledelseserfaringer opsamlet gennem en længere årrække, mens de to andre er yngre og derfor har haft færre år (mindre end ti år) som ledere bag sig. Hvad angår de øvrige medvirkende i projektet, der deltager som respondenter og informanter, og som er blevet interviewet gennem undersøgelsens virksomhedsbesøg i det første år, omfatter det én i den mindste og seks ledere i den største virksomhed. Disse ledere er henholdsvis souschefer og funktionsledere inden for salg, udvikling, design, produktion og finanser. Herudover har et større antal ledere og specialister, herunder flere af de ovenfor nævnte, medvirket i de møder og seminarer, vi har observeret.

\section{StraWay-projektet trin for trin}

September 2009: Startseminar (i en større midtjysk by). Formål: præsentation af virksomheder, deres strategiske og innovative problemstillinger, præsentation af forskerne, vores koncept om strategi i praksis, metodik og forudsætninger for projektet. Seminaret blev afsluttes med en aftale om den praktiske fremgangsmåde. (Varighed cirka 3 timer). Resultat: De fire ledere tilsluttede sig projektet og dets idégrundlag.

Efteråret 2009 (oktober): Virksomhedsbesøg på de fire virksomheder i tre forskellige danske regioner, indeholdende et dybtgående, ustruktureret interview med lederen (ca. 2 timer), virksomhedspræsentation og dokumentstudier. Dette blev efterfulgt af caseskrivning om centrale strategiske og innovative emner i den enkelte virksomhed. Forskerne havde som nævnt ansvar for at aftale besøg og for udformning af case, som efterfølgende blev suppleret af virksomhedens leder. (inklusive transport tog hvert besøg cirka en hel arbejdsdag)

November 2009: 2. seminar (igen i samme midtjyske by), hvor cases fra de deltagende virksomheder blev diskuteret, og hvor der ud fra de konkrete strategiske udfordringer blev peget på fokusområder for det videre arbejde med projektet i den enkelte virksomhed. Den enkelte case præsenteres af lederen fra den enkelte virksomhed og diskuteres af alle seminardeltagere (Varighed 3 cirka timer). Resultat: Afklaring af strategiske udfordringer for hver virksomhed og en opsamling i skriftlig form fra forskerne på tværs af virksomhederne. 
Vinteren 2010 (januar - februar): Indsamling af data om specifikke strategiske processer som opfølgning på de behandlede "oktobercases". Dette skete gennem en ny runde af virksomhedsbesøg, hvor lederen ud over sig selv havde udpeget mellem en og fem medledere som informanter, som hver blev interviewet $i$ en periode mellem tre og fem kvarter om deres måde at se de udvalgte strategiske temaer og processer på. Disse interview var bevidst ustrukturerede for at sikre, at det blev informanternes fortællinger, som blev det styrende for forløbet. Lederen blev ved starten eller afslutningen af besøget kort involveret for at berette om "siden sidst". Resultat: Cases ud fra en flerfacetteret sum af data, som belyser forskellige sider af de centrale strategiske virksomhedstemaer. (Varighed: Inklusiv transport en lang dag i hver virksomhed)

Marts 2010: 3. seminar (foregik efter invitation hos en af virksomhederne) havde til formål gennem arbejde med konkrete cases om strategiske processer belyst fra flere sider i "januar/februarcasen" for på den måde at komme dybere ned i den hverdagspraksis, disse aktiviteter omfatter. Forskerne udformede på grundlag af de skrevne cases før seminaret et tema, som den enkelte leder kunne vælge at tale over, og som havde et fremadrettet perspektiv på virksomhedens strategiske temaer (Varighed 4 timer).

Forsommer 2010 (april - maj): Virksomhedsbesøg med indsamling af data, som beskriver de løbende strategiske processer. Et formål med denne runde var om muligt at møde flere ledere i den samme virksomhed samtidig og observere dem i fællesskab, diskutere de strategiske udfordringer og studere kommunikationen omkring disse temaer. Dette skete i tre af virksomhederne gennem forskernes deltagelse i virksomhedsfastlagte strategiske seminarer og strategiske møder for ledere i virksomheden planlagt af ledelsen. I den fjerde virksomhed var der ikke i det tidsrum en passende lejlighed, så det blev i stedet til et gruppeinterview. Resultat: Cases, som var en afrapportering af praktisk strategisk ledelsesarbejde. (Varighed: Igen inklusiv transport en relativ lang dag i hver virksomhed).

Juni 2010: 4. seminar (foregik efter invitation hos en anden af virksomhederne) havde til formål at nå en række konklusioner omkring de måder, strategiske processer forløber på i de deltagende virksomheder. Specielt blev der lagt vægt på trianglen mellem produkt, organisation og marked. Caseresultater præsenteredes af lederne og blev diskuteres af alle i fællesskab (Varighed 4 timer).

Efteråret 2010 (august - september): Indsamling af data og diskussion mellem forskere og ledere i den enkelte virksomhed om succeser og vanskeligheder i forbindelse med gennemførelsen af strategiske aktiviteter. Foretages gennem virksomhedsbesøg og i form af relativt intensive interviews med de fire ledere efter en række individuelle nøglepunkter formidlet til dem gennem tilbagemeldingerne fra juniseminaret. Casene, som udarbejdes, vil blive forsøgt udformet som skitser til strategiske handlingsplaner for den efterfølgende periode.

Oktober 2010: 5. seminar, som har til formål at analysere handlingsplaner for det fortsatte arbejde med spredning og forankring af strategi i den enkelte virksomhed. Arbejdet vil foregå i fællesskab i den samlede seminarkreds (Varighed cirka 4 timer).

Vinter 2010/11: De enkelte ledere arbejder med udmøntning af handlingsplaner for effektivisering af det strategiske og innovative arbejde. Forskerne følger arbejdet og kan, hvis det skønnes hensigtsmæssigt, deltage som medspiller i specielt udvalgte problemstillinger. 
Forår 2011: 6. seminar, hvor de foreløbige resultater af handlingsplanerne diskuteres og vurderes (Varighed 4 timer).

Forsommer 2011: Besøgsrunde, hvor leder og udvalgte informanter interviewes om, hvordan virksomheden indtil da har klaret krisen, og hvilke forandringer der er sket i arbejdet med strategiske og innovative opgaver.

Efterår 2011: 6. seminar, hvor projektets samarbejdende del afsluttes gennem en evaluering af, hvad der er sket af forbedringer i den enkelte virksomhed vedrørende arbejde med centrale strategiske og innovative opgaver, og hvor den enkelte deltager er blevet mere kompetent inden for disse opgaver. Alle medvirkende deltager med mundtlige bidrag til alle evalueringer (Varighed 3 timer).

\section{Metodikkens muligheder og kritiske punkter}

Denne forløbsbeskrivelse af StraWay-projektet udtrykker, at metodikken hele tiden søger at skabe to spor. Et spor, der retter sig mod forskning i et relativt traditionelt koncept, som opfylder forskningskriterier for kvalitative studier, som de er beskrevet her i artiklen, og giver materiale til skrivning af papers og artikler. Og et spor, som gør det muligt for lederne at blive mere bevidste om egne overvejelser og handlinger i strategiske processer, og at de på den måde vil kunne opbygge nye og brugbare ledelseserfaringer. Disse to spor skal samtidig ses som tæt indvævet $\mathrm{i}$ hinanden, hvilket er en konsekvens af såvel paradigmet som af metodikkens karakter og en forudsætning for, at der kan ske erkendelse på tværs af den enkelte virksomhed.

Paradigmet forudsætter, at sådanne uformelle og næsten intuitive processer, som ligger bag virksomhedernes formulerede strategier, kun kan eksternaliseres og analyseres i en dialog mellem ledere og forskere. Og som, når det lykkes, fører til synteser, der bliver teser for en fortsat udforskning på feltet. Samtidig handler det om, at skal såvel ledere som forskere involveres i en sådan proces og udvikle et egentligt samarbejde om dette, kræver det, at det giver anvendelige resultater for alle. Herigennem understreges projektets pragmatiske karakter.

\section{Pragmatisk: Hoad der virker}

Pragmatisk kan her defineres som det, at noget virker. Spørgsmålet er så, hvilke mål det virker for opfyldelsen af. For lederne er det ret tydeligt, idet deres kriterier synes at være, om de når nye erkendelser til gavn for virksomheden og for deres funktion som ledere. Det er sammen med en vis portion nysgerrighed deres motivation til deltagelse. Hvad der virker for forskerne, ud over at det er deres arbejde, er straks lidt vanskeligere at beskrive. Det hænger sammen med, at metodikken ikke har til formål at be- eller afkræfte teorier eller modeller. Det gør praksis så at sige helt af sig selv. Uanset hvor mange teorier eller modeller, der på det strategiske område menes at kunne udsige noget om, hvordan der skal handles i praksis, så tyder meget på, at de ikke i praksis giver ledere brugbare redskaber. Derfor er det et formål i sig selv at kunne afdække praksisser og dermed den diversitet, der hersker. Det gælder, selv om det aldrig kan føre i retning af nogen Grand Theory for strategi.

Den pragmatiske tilgang har også noget at gøre med, at eksempelvis de fire ledere, der deltager i StraWay-projektet - og det samme var gældende for de femten, der deltog i det tidligere StraConprojekt, gør det med et forbrug af tid, der tages enten af deres øvrige arbejdstid eller deres fritid. 
Derfor skal de kunne opnå ny viden, der er til gavn for dem i deres arbejde. Det er en forudsætning for at få et sådant projekt til at fungere. Men det er samtidig en kilde til problemer, idet det betyder, at projektet hele tiden skal tage højde for den forståelse af ledelse og den omgangstone for ledere, som gælder i et sådan "community of practice". Der er på den ene side en oplevelse hos lederne af, at det at beskæftige sig med deres egen verden på denne måde, er spændende. Men der er også nogle utydelige grænser, som der måske kan skubbes til, men som ikke bør overtrædes.

\section{Svagheder i metodikken}

Den grænse, som mest tydelig har vist sig, kan siges at handle om kontrol. Den er utydelig, hvilket særligt har vist sig i StraWay-projektet, fordi projektet løber over så relativ lang tid, og at forskerne og lederne - og lederne indbyrdes har lært hinanden at kende så godt, at vi har opbygget en form for fortrolighed til hinanden. Det betyder, så vidt vi kan bedømme ud fra deres udsagn, at lederne optræder åbent, når de interviewes, og når de diskuterer cases. De er tillige åbne for at finde informanter til vore besøgsrunder i virksomhederne. De ved og accepterer, at vi til tider får meget forskellige og kritiske billeder af, hvilke opfattelser og forståelser der bevæger sig omkring i deres virksomhed. Og de accepterer, at sådanne forskellige forståelser fremtræder i casene.

Der, hvor kontrolgrænsen går pt., viser sig, når vi gennem kladder til casene til juni 2010 seminaret rapporterede om synspunkter, forståelser og beslutningsprocesser, som vi hører og oplever dem specielt på strategimøder i virksomhederne. I flere tilfælde har arbejdet med at skrive en endelig casetekst ud fra sådanne data krævet møder og samtaler med flere af vore nøgleaktører. Det hænger tilsyneladende sammen med, at usikkerhed omkring, hvilken strategi virksomheden konkret skal vælge, er ok at diskutere i en lukket kreds i en periode med alvorlig økonomisk krise. Men noget, der ligner rod og uklarhed i møder blandt lederne, er tilsyneladende at komme tæt på en norm for god virksomhedsledelse. Tilsvarende er konstateringer af, at forskerne som en form for "neutrale" observatører, ser andre forløb i sådanne møder, end de officielle interne referatskrivere gør, noget, som kan ses som værende på kanten af et normbrud.

Hvis dette er en temporær eller måske permanent grænse i en sådan produktion af viden, hvad betyder det for en undersøgelse udført med en sådan metodik? Svaret på det kan være todelt. Den ene del af svaret kan være, at ledere gerne vil blive klogere på, hvorledes strategiske beslutninger og handlinger er præget af intuitive og erfaringsbaserede overvejelser, men de er ikke lige så villige til at vise andre ledere, hvor virksomheden eller ledelsen efter deres normer ikke slår til i mere operative forløb omkring analyse og beslutningsprocesser.

Den anden del kan være, at der er et slør, som ledere og andre aktører bevidst eller ubevidst ikke vil lade rive væk. At denne anden del kan være i funktion, er i sig selv en begrundelse for at forske på den måde, som denne metodik lægger op til. Det hænger sammen med, at et sådant slør vil kunne være i funktion omkring alle observationer, interview og samtaler om kritiske emner uanset det paradigme, der ligger bag en undersøgelse, og den metodik, der anvendes. Hvis det er således, skal metodikken ses som en hjælp til at få lettet lidt på et sådant slør. Netop det at ikke alene forskernes interaktion med lederne i casearbejdet og ledernes indbyrdes interaktion på seminarerne skaber ny forståelse, men også det, at de forandrede syn på strategiske muligheder og problemer, som den samlede metodik giver, skaber forandringer, der i et lewinsk perspektiv er en betingelse for at forstå. 
Kritiske, men nødvendige svagheder

Dette rejser ontologiske spørgsmål. Det hænger sammen med, at dette kræver af forskerne, at de går aktivt med ind $\mathrm{i}$ den produktion af viden omkring den tavse, erfaringsbaserede og internaliserede viden. Hvis hverdagens til tider rodede gøremål skal undersøges, kan det kun gøres gennem, hvad jeg her vil kalde en fortolkningsbaseret version af aktionsforskning og action learning. En version, hvor forskeren selv indgår i direkte og aktive relationer med aktørerne på feltet, og hvor erkendelsen er, at den viden, der kommer ud af processen, ikke kan blive mere end det, som kan skabes i synergi gennem de analytiske evner og vilje, som findes hos henholdsvis aktører og forskere.

Pointen bag den metodik, der anvendes her, er, at enten accepteres det, at viden om sådanne processer kan produceres på denne vis. I så tilfælde er det en accept af en metode, hvor ledere og forskere sammen arbejder med at forstå processerne gennem at arbejde med disse. Eller også accepteres en sådan tilgang ikke. I sidste tilfælde må det betyde enten, at andre forskere må udvikle andre metodikker baseret på andre ontologiske forudsætninger, eller også at opgive at beskæftige sig med sådanne uklare og måske ufærdige fænomener.

Resultater: Forskellige, modsatrettede og sammenfiltrede billeder af strategiske processer

Det andet kritiske, ontologiske spørgsmål handler om, hvad det er, ledere og forskere ser. Eksemplet kan også her være de billeder, som et strategimøde skaber. Det handler om graden af fælles indforståethed, som udvikles i en ledelsesgruppe i en virksomhed. Accepten hos lederne af, at der i interview og samtaler med et udsnit af ledere dukker mange forskellige og modsatrettede billeder af strategiske problemer op, kan ses som bemærkelsesværdigt. Det gælder særligt, når der ses på den forsigtighed, som lederne behandler analyserne af strategimøderne med. Det ligner en modsætning, og det er det måske også.

Pointen kan være, at i praktisk strategisk ledelse kan to billeder, som tilsyneladende er modsætningsfyldte, stå ved siden af hinanden. Det ene peger på de mange forskellige og modsatrettede opfattelser om strategiske muligheder og problemer, der brydes i en virksomhed. Det andet billede handler om den indforståethed om i fællesskab at arbejde med det meshwork, som gør det muligt at skabe en fælles retning ud fra disse mange forskellige billeder. Det, som metodikken på den måde nærmer sig, kan være en forståelse af, at der inden for rammer, der er bestemt af virksomhedens historie, vaner, rutiner og af ledelsen forståelse af sin rolle, sideløbende kan bevæge sig flere strategiske diskurser og tillades indspark fra andre, f.eks. lederne i StraWayprojektet. Det hæmmer ikke, men fremmer den strategisk udvikling i virksomheden.

\section{Afrunding}

Denne artikel kan i sig selv siges at være et led i et udviklingsprojekt, hvor en metodik formes, samtidig med at den anvendes. Metodikken var fra begyndelsen udarbejdet som et praktisk redskab, der samlede en flok forskere omkring et fælles tema, som var at undersøge, om strategiske teorier og modeller nu også blev brugt i praksis i små og mellemstore virksomheder. Det startede en udviklingsproces, der først introducerede involvering af praktikere og derefter fælles skrivning af cases mellem forskere og ledere. Det var en proces, hvor viden om feltets karakteristika fik indflydelse på den måde, metodikken blev sat sammen på. Det var en pragmatisk fremgangsmåde, som gennem at arbejde eksplorativt skulle give noget til alle forskere uanset fag og paradigme. 
På et tidspunkt viste resultater, at uformelle processer, intuition og erfaringsbaseret viden er meget betydningsfulde for den måde, ledere af små og mellemstore virksomheder arbejder med strategi. Dette motiverer til at bevæge projekter i en fortolkende retning. Eller sagt på anden måde, så inspirerer det de forskere, der arbejder inden for et sådant paradigme. Det ændrer ikke ved den måde, de første eksplorative resultater kan forstås, men vægtede arbejdet med hverdagssprog, fortolkning og relationer for på den måde at kunne forstå det implicitte og erfaringsbaserede. Udgangspunktet er den måde, ledere præsenterer og forklarer deres strategier. Det er sjældent skrevet ned, det er ofte end ikke på forhånd formuleret mundtligt, og det er ikke overensstemmende med lærebogsmodeller. Eksplicit viden om dette skal derfor produceres mellem dem, der praktiserer: ledere og dem, som er specialister i at understøtte en sådan produktion af viden: forskere.

Denne problemstilling åbner for at arbejde med det, som StraWay-projektet har udviklet som ambition. Det er gennem at arbejde med de forstålser, der skabes gennem de relationer, der i virksomheder tillader og fremmer forskellige billeder af den strategiske fremtid, Men tillige af en kompleks nutid og af et stadigt retrospektivt arbejde med at forstå og bruge virksomhedens historie. Arbejdet med at forstå disse processer og relationer er alt andet end enkelt, specielt fordi mainstreamteorier og modeller betyder så lidt i ledelsespraksis. Derfor kunne det være fristende at omskrive et Kurt Lewin citat til: Der er ikke noget så praktisk som en god kvalitativ metodik.

\section{Referencer}

Ahlstrand, B., J. Lampel \& H. Mintzberg (1998). Strategy Safari. Hemel Hempstead: Prentice Hall Europe

Andersen, I. (2008). Den skinbarlige virkelighed. Gylling: Samfundslitteratur, 3. udg.

Ansoff, H.I. \& E. McDonnell (1990). Implanting Strategic Management. Cambridge: Prentice Hall, $2^{\text {nd }}$ ed.

Arbnor, I. \& B. Bjerke (2009). Methodology for Creating Business Knowledge. London: SAGE Publication, $3^{\text {rd }}$ ed.

Arbnor, I. \& B. Bjerke (1977). Företagsekonomisk Metodlära. Lund: Studentlitteratur

Berger, P. \& T.Luckmann (1976). Den samfundsskabte virkelighed. Viborg: Lindhart og Ringhof

Carson, D., A. Gilmore. C. Perry \& K. Gronhaug (2005). Qualitative Marketing Research. London: SAGE Publications

Carter, C., S.R. Clegg and M. Kornberger (2008). Strategy as practice? Strategic Organization, 6: 8399

Chia, R. \& R. Holt (2009). Strategy without Design. The Silent Efficacy of Indirect Action. Cambridge: Cambridge University Press 
Chia, R. \& R. Holt (2008). Strategy as wayfinding. Paper for The 24 ${ }^{\text {th }}$ Egos Colloquium Amsterdam, July 2008

Chia, R \& H. Tsoukas (2002). Organizational Becoming: Rethinking Organizational Change. Organisation Science, 13: 567-582

Clark, W.W. \& M. Fast (2008). Qualitative Economics. Toward a Science of Economics. Oxford: Coxmore Publishing Company

Clegg, S. C. Hardy \& W.R. Nord (1996). Handbook of Organization Studies. London: SAGE

Cummings, S. (2002). Recreating Strategy. London: SAGE Publications

Czarniawska, B. (2004). Narratives in Social Science Research. London: SAGE

De Witt, B. \& R. Meyer (2010). Strategy. Process, Content, Context. An International Perspective. Singapore: South-Western Cengage Learing, $4^{\text {th }}$ ed.

Dickens, L. \& K. Watkins (1999). Action Research: Rethinking Lewin, Management Learning. Jun 1999, Vol. 30, No. 2, 127-40

French, W.L. \& C.H. Bell (1999). Organization Development. Behavioral Science Interventions for Organization Improvement. Upper Saddle River NJ: Prentice Hall

Gelsing, L., A.N. Gjerding, T. Nielsen, J.G. Rasmussen \& A.L. Vinding (2008). Virksomheders hverdagsstrategier. Frederiksberg: Forlaget Samfundslitteratur

Gergen, K.J. \& T. J. Thatchenkery (2004). Organization Science as Social Construction. The Journal of Applied Behavioral Science. June 2004; 40, 2:228-49

Gregersen, B., L.T. Linde \& J.G. Rasmussen (2009). Linking between Danish universities and society. Public Policy, Vol. 36, No. 2: 151-156

Ingold, T. (2000). Lines. A Brief Story. London: Routledge

Jarzabkowski, P., J. Balogun \& D. Seidl (2007). Strategizing: The challenges of a practice perspective. Human Relations, 60: 5-27

Johnson, G., K. Scholes, R. Whittington (2008). Exploring Corporate Strategy. Harlow: Prentice Hall, $7^{\text {th }}$ ed.

Johnson, G., A. Langly, L. Melin \& R. Whittington (2008B). Strategy as Practice. Cambridge: Cambridge University Press

Jørgensen, K. M. \& P. Rasmussen (red.) (2005). Forandringsprojekter som organisatorisk læring. Aalborg: Aalborg Universitetsforlag 
Kvale, S. (2000). InterView. En introduktion til det kvalitative forskningsinterview. Gylling: Hans Reitzels Forlag a/s

Larsen, M.V. (2008). Strategisk ledelseskommunikation set i et fortolkende perspektiv. Paper for Det danske Ledelsesakademis konference i København, 8.-9. december 2008

Larsen, M.V. \& J.G. Rasmussen (2009). Praktisk metodik til forståelse af strategiske ledelsesudfordringer. Paper til Det Danske Ledelsesakademis konference i Odense, 7.- 8. december 2009

Larsen, M.V. \& J.G. Rasmussen (2008A). Strategizing by routines. The $24^{\text {th }}$ Egos Colloquium Amsterdam, July 2008

Larsen, M.V. \& J.G. Rasmussen (2008B). Kommunikation af strategisk forandring i virksomhedens hverdag - del 1 og 2, Børsens Ledelseshåndbøger: Innovations og forandringsledelse. April 2008

Larsen, M.V. \& J.G. Rasmussen (2007). Strategi, forandring, kommunikation. Paper til Det danske Ledelsesakademis konference i Århus, 10.-11. december 2007

Laursen E. \& J.G. Rasmussen (red.) (2007). Organisatorisk læring gennem udviklingsprojekter. Aalborg: Aalborg Universitetsforlag, 2007.

Lynch, R. (2003). Corporate Strategy. Harlow: FT Prentice Hall, 3'rd ed.

Marsick, V.J. \& J. O'Neal (1999). The Many Faces of Action Learning. Management Learning, Jun.1999, Vol. 30, No. 2:159-76

Mathisen, T. (1973). Det ufærdige. Bidrag til en politisk aktionsteori. Herlev: Hans Reitzel

Mintzberg, H. (1994). The Rise and Fall of Strategic Planning. Harlow: FT Prentice Hall

Mintzberg, H. (1978). Patterns in Strategy Formation. Management Science. Vol. 24, No. 9, 934-948

Nonaka I. \& H. Takeuchi (1995). The Knowledge Creating Company. New York: Oxford University Press

Rasmussen, J.G. (2008). Strategisk praksis set i et fortolkende perspektiv. Paper til Det Danske Ledelsesakademis konference, december 2008

Rasmussen, J.G. (2006). Konceptualisering af virksomheders hverdagsstrategi: Lederes arbejde med strategi. Paper til Det Danske Ledelsesakademis konference i København, december 2006.

Rasmussen, J.G. (2001). Managing the Learning Cell. Processes of Change in the Governance Structures of Universities. Aalborg: Aalborg University 
Qualitative Studies, 1(2)

Revans, R.W. (1992). What is Action Learning? Journal of Management Development, Vol.1, No. 3:64-75

Robson, C. (2002). Real World Research. Padstow: Blackwell Publishing, $2^{\text {nd }}$ ed.

Schütz, A. (1970). The Phenomenology of the Social World. Chicago: The University of Chicago Press.

Schütz, A. \& T. Luckmann (1973). The Structures of the Life-World. Evanston: North-Western University Press

Weick, K.E., K.M. Sutcliffe \& D. Obstfeld (2005). Organizing and the Process of Sensemaking. Organization Science, 16: 409-421.

Whittington, R., P. Jarzabkowski, M. Mayer, E. Mounoud, J. Nahapiet \& L. Roleau (2003). Taking Strategy seriously. Responsibility and Reform for an Important Social Practice. Journal of Management Inquiry, 12: 396-409

Whittington, R., E. Molloy, M. Mayer \& A. Smith (2006). Practice of Strategising/Organising. Broadening Strategic Work and Skills, Long Range Planning, 39: 615-629.

Yin, R.K. (1989). Case Study Research: design and methods. London: SAGE, 2nd ed.

\section{Forfatter}

Jørgen Gulddahl Rasmussen er Professor på Institut for Erhvervsstudier, Aalborg Universitet. Email: jgr@business.aau.dk 